Prepared in cooperation with the Colorado River Water Conservation District

Selenium and Mercury Concentrations in Fish, Wolford Mountain Reservoir, Colorado, 2005

Scientific Investigations Report 2007-5019 
COVER PHOTOGRAPH: Wolford Mountain Reservoir, June 2005.

Photograph courtesy of Nancy J. Bauch, U.S. Geological Survey. 


\section{Selenium and Mercury Concentrations in Fish, Wolford Mountain Reservoir, Colorado, 2005}

By Nancy J. Bauch

Prepared in cooperation with the Colorado River Water Conservation District

Scientific Investigations Report 2007-5019 


\section{U.S. Department of the Interior DIRK KEMPTHORNE, Secretary}

\section{U.S. Geological Survey \\ Mark D. Myers, Director}

\section{U.S. Geological Survey, Reston, Virginia: 2007}

For product and ordering information:

World Wide Web: http://www.usgs.gov/pubprod

Telephone: 1-888-ASK-USGS

For more information on the USGS--the Federal source for science about the Earth, its natural and living resources, natural hazards, and the environment:

World Wide Web: http://www.usgs.gov

Telephone: 1-888-ASK-USGS

Any use of trade, product, or firm names is for descriptive purposes only and does not imply endorsement by the U.S. Government.

Although this report is in the public domain, permission must be secured from the individual copyright owners to reproduce any copyrighted materials contained within this report.

Suggested citation:

Bauch, N.J., 2007, Selenium and mercury concentrations in fish, Wolford Mountain Reservoir, Colorado, 2005:

U.S. Geological Survey Scientific Investigations Report 2007-5019, 17 p. 


\section{Contents}

Abstract
Introduction.
Purpose and Scope
Description of Study Area
Data Collection
Sample Collection
Selenium and Mercury Concentrations in Fish
Summary and Conclusions
References Cited.
Appendix.

\section{Figures}

1. Map showing location of fish-collection sites in Wolford Mountain Reservoir, Colorado, June 2005, and historic water-quality sampling sites in Muddy Creek, Alkali Slough, and Wolford Mountain Reservoir.

2. Graph showing historic concentrations of dissolved selenium in Muddy Creek, (between 1990 and 2005), Alkali Slough (between 1995 and 2004), and Wolford Mountain Reservoir (between 1995 and 2005), Colorado

\section{Tables}

1. Fish-collection sites in Wolford Mountain Reservoir, Colorado, June 2005, and historic water-quality sampling sites in Muddy Creek, Alkali Slough, and Wolford

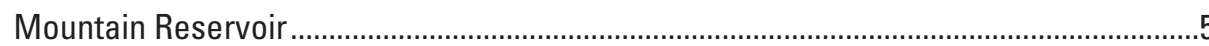

2. Concentrations of selenium and total mercury in fish collected at three sites in Wolford Mountain Reservoir, Colorado, June 2005.

\section{Appendix}

Historic concentrations of dissolved selenium and total mercury in Muddy Creek, Alkali Slough, and Wolford Mountain Reservoir near Kremmling, Colorado 


\section{Conversion Factors and Abbreviations}

\begin{tabular}{lcl}
\hline Multiply & By & To obtain \\
\hline acre & 4,047 & square meter \\
acre-foot $($ acre-ft) & 1,233 & cubic meter \\
centimeter $(\mathrm{cm})$ & 0.3937 & inch \\
cubic foot per second $\left(\mathrm{ft} \mathrm{f}^{3} / \mathrm{s}\right)$ & 0.02832 & cubic meter per second \\
foot $(\mathrm{ft})$ & 0.3048 & meter \\
gram $(\mathrm{g})$ & 0.03527 & ounce, avoirdupois \\
inch $($ in.) & 2.54 & centimeter \\
microgram per gram $(\mu \mathrm{g} / \mathrm{g})$ & 1 & milligram per kilogram \\
microgram per gram $(\mu \mathrm{g} / \mathrm{g})$ & 1 & part per million $(\mathrm{ppm})$ \\
microgram per liter $(\mu \mathrm{g} / \mathrm{L})$ & 1 & part per billion $(\mathrm{ppb})$ \\
mile $($ mi $)$ & 1.609 & kilometer \\
millimeter $(\mathrm{mm})$ & 0.03937 & inch \\
\hline
\end{tabular}

Temperature in degrees Celsius $\left({ }^{\circ} \mathrm{C}\right)$ may be converted to degrees Fahrenheit $\left({ }^{\circ} \mathrm{F}\right)$ as follows: ${ }^{\circ} \mathrm{F}=\left(1.8 x^{\circ} \mathrm{C}\right)+32$

\section{Additional Abbreviations}

CDOW: Colorado Division of Wildlife

CRV: $\quad$ Certified reference value

CRWCD: Colorado River Water Conservation District

CWRUL: Cooperative Wildlife Research Unit Laboratory

DOLT-2: Dogfish (Squalus acanthias) liver

DORM-2: Dogfish (Squalus acanthias) muscle

MDL: Method detection level

QA/QC: Quality assurance and quality control

RPD: $\quad$ Relative percent difference

SRM: Standard reference material

TERL: $\quad$ Trace Element Research Laboratory (at Texas A\&M University, College Station, Texas)

$\mu \mathrm{g} / \mathrm{m}^{2}: \quad$ microgram per square meter

$\mu \mathrm{g} / \mathrm{s}: \quad$ microgram per second

USEPA: U.S. Environmental Protection Agency

USFWS: U.S. Fish and Wildlife Service

USGS: $\quad$ U.S. Geological Survey 


\title{
Selenium and Mercury Concentrations in Fish, Wolford Mountain Reservoir, Colorado, 2005
}

\author{
By Nancy J. Bauch
}

\section{Abstract}

A reconnaissance investigation of selenium and total mercury in fish in Wolford Mountain Reservoir, Colorado, was conducted by the U.S. Geological Survey in June 2005, in cooperation with the Colorado River Water Conservation District. A total of 32 game and nongame fish were collected from three sites in the reservoir for analysis of selenium and total mercury. Five species of fish were sampled: white sucker (Catostomus commersonii, $\mathrm{n}=17$ ), brown trout (Salmo trutta, $\mathrm{n}=5$ ), rainbow trout (Oncorhynchus mykiss, $\mathrm{n}=5$ ), cutthroat trout (Oncorhynchus clarkii, $\mathrm{n}=3$ ), and splake (Salvelinus fontinalis $x$ Salvelinus namaycush, $\mathrm{n}=2$ ). Selenium concentrations ranged from 1.05 to 11.7 micrograms per gram (equivalent to parts per million or ppm) dry weight, whole body. Almost 22 percent ( 7 of 32) of fish samples had selenium concentrations greater than 7.91 micrograms per gram dry weight, the U.S. Environmental Protection Agency 2004 draft freshwater chronic criterion for selenium in whole-body fish tissue. Total mercury concentrations in muscle plug samples ranged from 0.012 to 0.320 microgram per gram wet weight. Concentrations of mercury in muscle plug samples are comparable to concentrations in fillet samples, and only one fish sample, a nongame white sucker, had a total mercury concentration greater than the U.S. Environmental Protection Agency water-quality criterion for the protection of human health of 0.3 microgram per gram wet weight in fillets. Converting muscle plug or fillet concentrations of mercury to whole-body concentrations, four fish samples (12.5 percent) had estimated whole-body total mercury concentrations greater than 0.1 microgram per gram wet weight concentration in wholebody fish tissue, the U.S. Fish and Wildlife Service criterion for protection of fish-eating birds and wildlife.

Water-quality data for dissolved selenium and total mercury in two tributaries and three reservoir sites were compiled and compared. Dissolved concentrations of selenium in one tributary and one reservoir site (prior to 1998) were greater than 4.6 micrograms per liter, the State of Colorado chronic water-quality standard for dissolved selenium for protection of aquatic life. Total mercury concentrations in most water samples from two tributaries and three reservoir sites were less than or equal to 0.01 microgram per liter, the State of Colorado chronic water-quality standard for total mercury for protection of aquatic life. Selenium and mercury in fish in Wolford Mountain Reservoir most likely are not directly related to selenium and mercury concentrations in reservoir water, as most selenium and mercury in fish tissue results from the presence of selenium and mercury in the diet rather than through gill uptake from water.

Results of this reconnaissance investigation of selenium and total mercury in fish in Wolford Mountain Reservoir indicate that concentrations of selenium were elevated in some fish. Most total mercury concentrations in fish were less than criteria levels.

\section{Introduction}

Selenium and mercury are trace elements that bioaccumulate in fish and wildlife and are toxic at high concentrations. Selenium is an essential trace nutrient, but there is a very narrow margin between being nutritionally optimal and toxic to fish and wildlife. Selenium occurs as a natural element in aquatic ecosystems in the Western United States through the natural weathering of Upper Cretaceous marine sedimentary rocks and Tertiary marine and continental sedimentary deposits (Seiler and others, 2003). Irrigation applied to seleniferous soils derived from these sedimentary rocks and deposits can mobilize and introduce selenium to aquatic ecosystems through the drainage of irrigation return flows to nearby water bodies. Selenium also can be introduced through the disposal of fly ash from coal combustion. Excessive concentrations of selenium are most acutely felt in the larval stage of fish and in the embryo stage of birds (Lemly, 1998; Heinz, 1996). Deformities in fish may include abnormal curvature of the spine and deformed or missing eyes or fins. In birds, deformed chicks cannot hatch (Seiler and others, 2003).

Mercury occurs naturally in the environment as the rock cinnabar (mercury sulfide) and in volcanic gases. The dominant source of mercury to most aquatic ecosystems is atmospheric deposition of mercury, primarily from human activity through coal-combustion electrical power generation (National Research Council, 2000). It is estimated that wet deposition of mercury accounts for 50 to 90 percent of the mercury 
load to many inland United States water bodies and estuaries (National Atmospheric Deposition Program and Illinois State Water Survey, 2005). Total mercury wet deposition in 2005 at two sites in Colorado was 5.4 and 8.6 micrograms per square meter $\left(\mu \mathrm{g} / \mathrm{m}^{2}\right)$; deposition for 77 other sites across the Nation ranged from 2.5 to $21.5 \mu \mathrm{g} / \mathrm{m}^{2}$ (National Atmospheric Deposition Program, 2005). Anthropogenic mercury emissions have resulted in widespread elevation of mercury concentrations in some aquatic ecosystems throughout the world, relative to pre-industrial times (Swain and others, 1992). Aquatic ecosystems also may contain high levels of mercury due to the presence of cinnabar, current or historical mercury or gold mining operations, and industrial releases of mercury.

In the environment, mercury can be converted by microorganisms in soil and sediment to methylmercury, a potent neurotoxin that affects the central nervous system (National Research Council, 2000). Methylmercury readily crosses biological membranes and can accumulate to harmful concentrations in exposed organisms and biomagnify in aquatic food webs, posing a threat to humans and fish-eating wildlife (Krabbenhoft and others, 1999). Depending on environmental conditions, newly created reservoirs can have high rates of mercury methylation (Bodaly and others, 1997; St. Louis and others, 2004). Selenium can protect against mercury exposure by suppressing mercury bioavailability (Belzile and others, 2006; Chen and others, 2001; Raymond and Ralston, 2004).

Wolford Mountain Reservoir, in north-central Colorado near Kremmling (fig. 1), was constructed between 1992 and 1994 and began to fill during 1995. Lower elevation areas of the reservoir's watershed and most of the length of the main tributary Muddy Creek are underlain by the Pierre Shale, an Upper Cretaceous marine formation containing selenium (Tweto, 1979; Ruddy, 1987). Selenium concentrations in Alkali Slough, another tributary to the reservoir, have exceeded chronic (4.6 micrograms per liter, $\mu \mathrm{g} / \mathrm{L})$ or acute $(18.4 \mu \mathrm{g} / \mathrm{L})$ State of Colorado aquatic life water-quality standards (Stevens and Sprague, 2003; appendix). The nearest potential anthropogenic source of mercury emissions to the reservoir is a coalfired electrical-generating power plant, about 65 mi northwest of the reservoir. With these considerations, U.S. Geological Survey (USGS) scientists, in cooperation with the Colorado River Water Conservation District (CRWCD), conducted a reconnaissance investigation of selenium and total mercury in game and nongame fish in Wolford Mountain Reservoir in June 2005. This study represents the first assessment of trace elements in fish from Wolford Mountain Reservoir and will provide useful baseline data for assessing potential changes in selenium and total mercury in fish over time.

\section{Purpose and Scope}

This report describes the results of the reconnaissance investigation of selenium and total mercury concentrations in fish tissue at three sites in Wolford Mountain Reservoir during June 2005. Concentrations of selenium and total mercury in fish samples are compared to U.S. Environmental Protection
Agency (USEPA) aquatic-life and water-quality criteria, fish-consumption advisories, U.S. Fish and Wildlife Service (USFWS) criterion for the protection of wildlife, and threshold effect levels. Concentrations also are compared to fish data collected from other field and laboratory studies, and dissolved selenium and total mercury concentrations in the reservoir and in two tributaries.

\section{Description of Study Area}

Wolford Mountain Reservoir, created by the impoundment of Muddy Creek, is $5 \mathrm{mi}$ north of Kremmling, Colorado (fig. 1). The reservoir, owned and operated by the CRWCD, covers 1,550 acres and has storage of 66,000 acre-feet at capacity (Colorado River Water Conservation District, 2006). The long and narrow reservoir has a length of about $4.5 \mathrm{mi}$ and is one-quarter to one-half mile wide at full capacity. Several embayments and coves are located on the western shore where tributaries enter the reservoir. Intermittent tributaries to the reservoir include Pinto Creek, Pass Creek, Red Dirt Creek, and Alkali Slough (Stevens and Sprague, 2003). Lower elevation areas of the Muddy Creek watershed are arid to semiarid, with average annual precipitation from 10 to 15 inches (Oregon State University, 2000). Agricultural activities on these sparsely vegetated, lower elevation lands include irrigated hay and grass production and rangeland (Stevens and Sprague, 2003).

The reservoir is a popular destination for fishing, camping, and recreation. Fishing opportunities are available year round, and the reservoir commonly is featured in the media for its fishing. The reservoir has routinely been stocked by the CRWCD and the Colorado Division of Wildlife (CDOW) with trout and kokanee salmon. White suckers, present in Muddy Creek before impoundment (J.A. Collins, U.S. Geological Survey, oral commun., 2005), are common in the reservoir.

\section{Acknowledgments}

The author thanks Bill Atkinson (CDOW) for his assistance in placing gill nets and fish collection; V. Cory Stephens and L. Rod DeWeese (USGS) for their assistance in fish collection and processing; and Mark Brigham and L. Rod DeWeese (USGS), and Barbara C. Osmundson and Richard P. Krueger (USFWS) for their technical assistance. Professor Robert Taylor at Texas A\&M University provided assistance on laboratory analytical techniques. Fish ages were determined by Professor Jeff Isely at Clemson University. Mark Brigham, L. Rod DeWeese, and Robin Stewart (USGS) provided technical reviews of the manuscript. The manuscript was edited by Carol Anderson. Layout and design were done by Joy Monson.

Figure 1 (facing page). Location of fish-collection sites in Wolford Mountain Reservoir, Colorado, June 2005, and historic water-quality sampling sites in Muddy Creek, Alkali Slough, and Wolford Mountain Reservoir. 

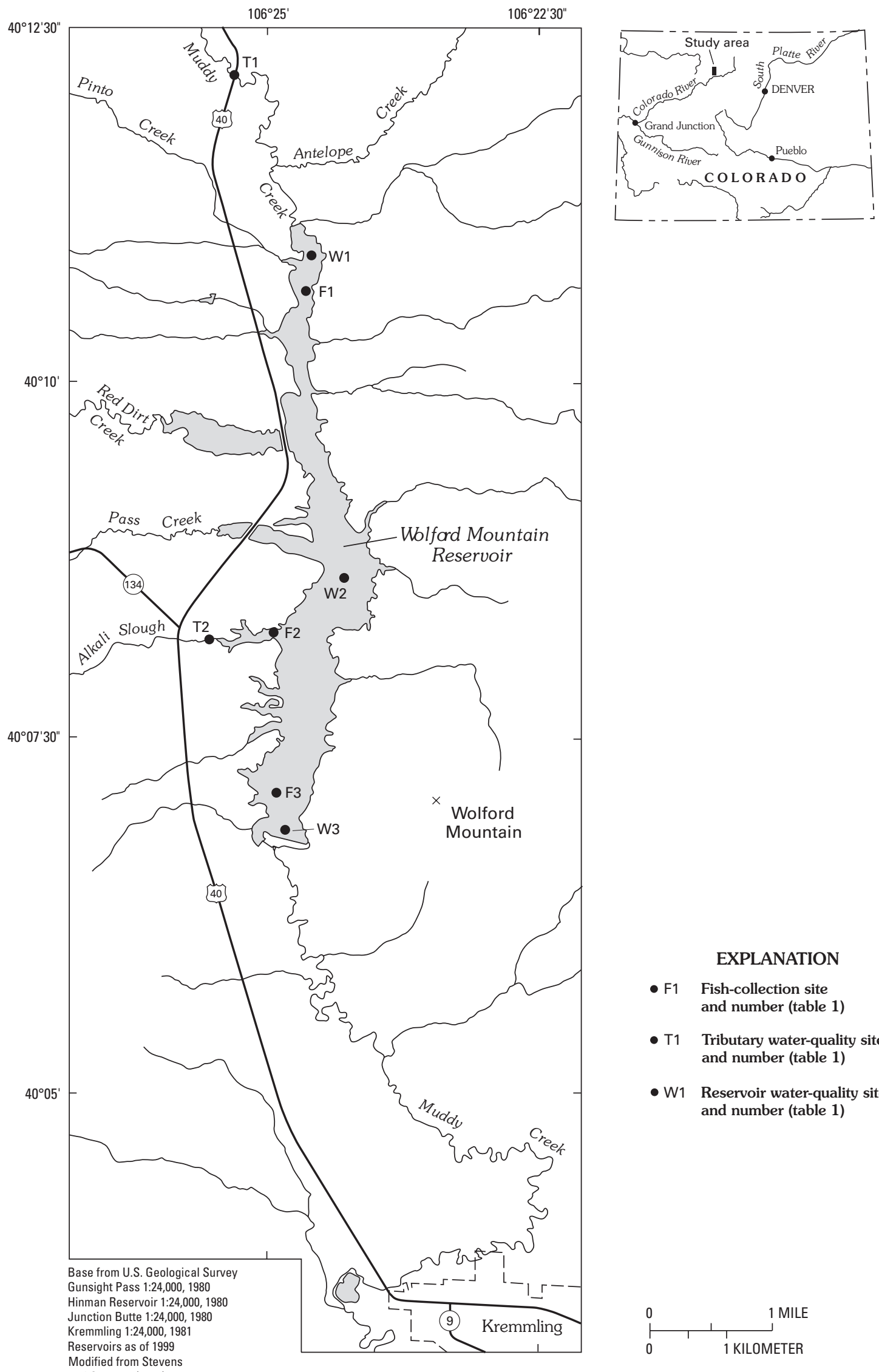

\section{EXPLANATION}

- F1 Fish-collection site and number (table 1)

- T1 Tributary water-quality site and number (table 1)

- W1 Reservoir water-quality site and number (table 1)

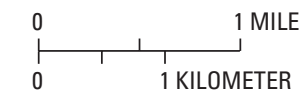




\section{Data Collection}

Sample collection, laboratory methods for selenium and total mercury analysis, and quality assurance and quality control are discussed in this section. Fish samples were analyzed for total mercury (henceforth referred to as "mercury" for fish) rather than methylmercury because virtually all of the mercury in fish is present as methylmercury (Bloom, 1992; Wiener and others, 2002).

\section{Sample Collection}

Experimental gill nets measuring 6 by $125 \mathrm{ft}$ were set at three sites in the reservoir (fig. 1, table 1) on June 15, 2005 , by CDOW personnel and retrieved on June 16, 2005. Each net was placed at different depths through a system of weights and floats (table 1) and remained in the water overnight for approximately 11 to 16 hours. With each net retrieval, all fish were removed from the net, and game and nongame fish were stored on ice for onshore measuring and processing for selenium and mercury analysis.

A maximum of 12 fish per site were measured for total length and weighed to the nearest gram. Three plugs of axial muscle from between the lateral line and dorsal fin area of each fish were removed for analysis of mercury content using a 6-millimeter AcuDerm punch; a new punch was used for each fish. Skin was removed from each plug with a stainless steel scalpel, and the three plugs for each fish were stored in a polypropylene vial on dry ice. Muscle plugs provide an accurate measure of mercury in fish fillet tissue (Baker and others, 2004; Pearson, 2000) and can be accurately converted to whole-body concentrations (Peterson and others, 2005).

Otoliths, inner ear bones of fish, were used to determine fish age. One or two otoliths from 23 fish were removed from the fish heads onsite, dried, and stored in vials prior to shipment to the laboratory. For nine fish, otoliths could not be removed onsite; the whole head was removed, frozen, and stored on dry ice for otolith removal in the laboratory. After removal of muscle plugs and the otoliths or head, the whole or headless fish were stored in plastic bags on dry ice for selenium analysis.

\section{Laboratory Methods for Selenium and Mercury Analysis}

Fish-tissue samples were shipped on dry ice to the Trace Element Research Laboratory (TERL) at Texas A\&M University in College Station, Texas, for determination of moisture, selenium, and mercury content. Moisture content was determined by weight loss upon freeze-drying and is reported as the weight percentage of the original wet sample. Freeze-dried samples were homogenized to a fine powder and then digested with nitric acid at 130 degrees Celsius prior to chemical analysis. The concentration of selenium in the digested fish samples was determined by hydride generation atomic fluorescence spectroscopy, and the concentration of mercury was determined by cold-vapor atomic absorption spectroscopy. Detailed descriptions of the laboratory methods for selenium and mercury analysis are reported in U.S. Fish and Wildlife Service (2006). Selenium and mercury concentrations are reported from the laboratory on a dry-weight basis and can be converted to a wet-weight (or live) basis using the measured moisture content of each sample.

Otoliths and frozen fish heads were shipped to the USGS Cooperative Wildlife Research Unit Laboratory (CWRUL) at Clemson University in Clemson, South Carolina. Fish age was determined using methods adapted from Nielsen and Johnson (1983). Otoliths first were divided into thin sections in the CWRUL. The age of the fish then was determined by counting annuli or rings of growth on the otolith, similar to the counting of tree rings for determination of tree age.

\section{Quality Assurance and Quality Control}

Quality assurance (QA) and quality control (QC) samples were analyzed at the TERL for selenium and mercury. These included procedural blanks, laboratory control samples, laboratory replicate samples, laboratory spiked samples, and standard reference material. Except for laboratory control samples, two samples of each type of QA/QC sample were analyzed for selenium; and three samples of each type of QA/QC sample, including two different standard reference materials, were analyzed for mercury. Two laboratory control samples only were analyzed for selenium. Replicate and spike sample analysis only included subsamples from individual homogenized fish in the laboratory. Samples were not collected from multiple fish and analyzed as replicate pairs or spiked samples because of the inherent variability of contaminant and other compound concentrations in fish.

Procedural blanks measure the amount of selenium or mercury that may be introduced in a sample during sample processing in the laboratory. One blank sample for selenium had a selenium concentration that was less than the method detection level (MDL), and the other blank sample had a selenium concentration of 0.022 microgram per gram $(\mu \mathrm{g} / \mathrm{g})$ (dry weight), which was slightly higher than the MDL of $0.0179 \mu \mathrm{g} / \mathrm{g}$ (dry weight). Of the three blank samples for mercury, one had a concentration that was less than the MDL, and the other two samples had concentrations equal to the MDL of $0.00004 \mu \mathrm{g} / \mathrm{g}$ (dry weight). The detection of selenium and mercury in blank samples with concentrations at or near the MDLs does not affect the analysis of selenium and mercury in the 32 fish samples collected in Wolford Mountain Reservoir because reported concentrations in the 32 fish samples were orders of magnitude higher than concentrations in the blanks samples.

Laboratory control samples were used to assess method performance for initial method validation and routine accuracy assessment. Percent recoveries of selenium for the two laboratory control samples were 105 and 109 percent. Laboratory control samples for mercury were not evaluated during the analysis of the Wolford Mountain Reservoir fish samples. 
Table 1. Fish-collection sites in Wolford Mountain Reservoir, Colorado, June 2005, and historic water-quality sampling sites in Muddy Creek, Alkali Slough, and Wolford Mountain Reservoir.

[USGS, U.S. Geological Survey; ft, feet; n/a, not applicable]

\begin{tabular}{|c|c|c|c|c|c|c|c|}
\hline $\begin{array}{l}\text { Site number } \\
\text { (figure 1) }\end{array}$ & Site name & Site abbreviation & $\begin{array}{l}\text { USGS site } \\
\text { identifier }\end{array}$ & $\begin{array}{l}\text { Sample } \\
\text { date }\end{array}$ & $\begin{array}{l}\text { Net placement } \\
\text { (ft below } \\
\text { water surface) }\end{array}$ & Latitude & Longitude \\
\hline \multicolumn{8}{|c|}{ Fish-collection site } \\
\hline $\mathrm{F} 1$ & $\begin{array}{l}\text { Wolford Mountain Reservoir near } \\
\text { Muddy Creek near Kremmling }\end{array}$ & near Muddy Creek & 401014106243901 & $6 / 16 / 05$ & $2-9$ & $40^{\circ} 10^{\prime} 14^{\prime \prime}$ & $106^{\circ} 24^{\prime} 39^{\prime \prime}$ \\
\hline $\mathrm{F} 2$ & $\begin{array}{l}\text { Wolford Mountain Reservoir at } \\
\text { Alkali Slough near Kremmling }\end{array}$ & near Alkali Slough & 400813106251501 & $6 / 16 / 05$ & $3-19$ & $40^{\circ} 08^{\prime} 13^{\prime \prime}$ & $106^{\circ} 25^{\prime} 15^{\prime \prime}$ \\
\hline F3 & $\begin{array}{l}\text { Wolford Mountain Reservoir near } \\
\text { dam near Kremmling }\end{array}$ & near dam & 400708106250701 & $6 / 16 / 05$ & $0-35$ & $40^{\circ} 07^{\prime} 08^{\prime \prime}$ & $106^{\circ} 25^{\prime} 07^{\prime \prime}$ \\
\hline \multicolumn{8}{|c|}{ Water-quality site } \\
\hline $\mathrm{T} 1$ & $\begin{array}{l}\text { Muddy Creek above Antelope Creek } \\
\text { near Kremmling }\end{array}$ & Muddy Creek & 09041090 & $1990-2005$ & $\mathrm{n} / \mathrm{a}$ & $40^{\circ} 12^{\prime} 09^{\prime \prime}$ & $106^{\circ} 25^{\prime} 19^{\prime \prime}$ \\
\hline $\mathrm{T} 2$ & $\begin{array}{l}\text { Alkali Slough \#2 at Wolford Mountain } \\
\text { Reservoir near Kremmling }\end{array}$ & Alkali Slough & 400812106254800 & 1995-2004 & $\mathrm{n} / \mathrm{a}$ & $40^{\circ} 08^{\prime} 12^{\prime \prime}$ & $106^{\circ} 25^{\prime} 48^{\prime \prime}$ \\
\hline W1 & $\begin{array}{l}\text { Wolford Mountain Reservoir at inflow } \\
\text { near Kremmling }\end{array}$ & inflow & 401110106244800 & 1996-2004 & $\mathrm{n} / \mathrm{a}$ & $40^{\circ} 11^{\prime} 10^{\prime \prime}$ & $106^{\circ} 24^{\prime} 48^{\prime \prime}$ \\
\hline W2 & $\begin{array}{l}\text { Wolford Mountain Reservoir at midlake } \\
\text { near Kremmling }\end{array}$ & midlake & 400841106240600 & 1995-2004 & $\mathrm{n} / \mathrm{a}$ & $40^{\circ} 08^{\prime} 41^{\prime \prime}$ & $106^{\circ} 24^{\prime} 06^{\prime \prime}$ \\
\hline W3 & $\begin{array}{l}\text { Wolford Mountain Reservoir near } \\
\text { Kremmling }\end{array}$ & near dam & 09041395 & $1995-2005$ & $\mathrm{n} / \mathrm{a}$ & $40^{\circ} 06^{\prime} 46^{\prime \prime}$ & $106^{\circ} 24^{\prime} 52^{\prime \prime}$ \\
\hline
\end{tabular}


Laboratory replicate samples are used to test for data variability. All replicate samples were created by taking subsamples from the original homogenized fish sample. By comparing the analytical results of the replicate pair (original sample and QA/QC sample), information is obtained on the precision of the methods used for analysis. Replicate samples were analyzed by calculating the relative percent difference (RPD) of the replicate pair-the absolute value of the difference between the replicate analyses divided by the average of the two analyses times 100 . The RPD values for the five replicate pairs ranged from 0.26 to 1.51 percent.

Laboratory spiked samples are used to measure the accuracy of analytical methods by determining the amount of spike recovery in a sample. Once the fish sample was homogenized, two subsamples were taken. One subsample was analyzed as a normal fish sample, and the other subsample was spiked with either $0.205 \mu \mathrm{g} / \mathrm{g}$ of selenium or $1.0 \mu \mathrm{g} / \mathrm{g}$ of mercury prior to analysis. Percent recoveries for the two spiked samples for selenium were 92 and 106 percent, and recoveries for the three spiked samples for mercury ranged from 99 to 102 percent.

A standard reference material (SRM) also is used to assess the accuracy of analytical methods. The SRM used by TERL for selenium fish tissue was the National Institute of Standards and Technology mussel tissue 2976, with a certified reference value $(\mathrm{CRV})$ of $1.8 \mu \mathrm{g} / \mathrm{g}$. The percent recoveries for the two analyses of SRM 2976 were 93 and 95 percent.

Two SRMs were used by TERL for mercury fish tissue: dogfish (Squalus acanthias) liver (DOLT-2) and dogfish (Squalus acanthias) muscle (DORM-2). Both are certified by the National Research Council of Canada, with DOLT-2 having a CRV of $2.14 \mu \mathrm{g} / \mathrm{g}$ mercury (dry weight), and DORM-2 having a CRV of $4.64 \mu \mathrm{g} / \mathrm{g}$ mercury (dry weight). The percent recoveries for three analyses of DOLT-2 ranged from 98 to 100 percent, and recoveries for three analyses of DORM-2 ranged from 96 to 101 percent.

In general, the quality of selenium and mercury determinations was excellent. Replicate sample analyses indicated excellent precision. Accuracy, as measured by percent recovery of spiked samples and SRMs also was excellent.

\section{Selenium and Mercury Concentrations in Fish}

A total of 32 game and nongame fish from 5 species were collected at 3 sites in Wolford Mountain Reservoir. At each site, all game fish and a maximum of six nongame fish were collected (table 2). A maximum of 12 fish were collected from each site. Most fish caught in the nets were white sucker (Catostomus commersonii), a nongame fish. Other fish caught in the nets and retrieved for processing and analysis were the game fish brown (Salmo trutta), rainbow (Oncorhynchus mykiss), and cutthroat (Oncorhynchus clarkii) trout and splake (Salvelinus fontinalis $x$ Salvelinus namaycush). Game fish typically are caught for human consumption, whereas nongame fish usually are not caught for human consumption. The abdominal cavities for two trout were removed for CDOW purposes and were not included for sample processing and analysis for this report.

Selenium concentrations in fish samples are discussed on a dry-weight basis; the draft USEPA aquatic life criterion for selenium is based on dry weight (U.S. Environmental Protection Agency, 2006). Mercury concentrations are discussed on a wet-weight basis. The USEPA water-quality criterion for mercury concentration in fish for protection of human health is based on a wet-weight concentration (U.S. Environmental Protection Agency, 2001).

Selenium concentrations in whole-body fish samples from Wolford Mountain Reservoir ranged from 1.05 to $11.7 \mu \mathrm{g} / \mathrm{g}$ dry weight (table 2). Almost 22 percent (7 of 32) of fish had concentrations greater than $7.91 \mu \mathrm{g} / \mathrm{g}$ dry weight, the USEPA 2004 draft freshwater chronic criterion for selenium in whole-body fish tissue (U.S. Environmental Protection Agency, 2006). The draft criterion states that if fish-tissue samples exceed $5.85 \mu \mathrm{g} / \mathrm{g}$ dry weight during summer or fall, fish should be monitored during the winter to determine if selenium exceeds $7.91 \mu \mathrm{g} / \mathrm{g}$ dry weight because of the uncertainty of juvenile fish concentrating selenium over the winter. Most (75 percent, 24 of 32) fish samples collected from Wolford Mountain Reservoir in June 2005 had selenium concentrations greater than $5.85 \mu \mathrm{g} / \mathrm{g}$ dry weight. The draft criterion value of $7.91 \mu \mathrm{g} / \mathrm{g}$ is undergoing further investigation by the USEPA, because there is some concern that the value may not adequately protect the health of fish and wildlife.

The maximum selenium concentration of $11.7 \mu \mathrm{g} / \mathrm{g}$ dry weight was detected in one brown trout sample (table 2). Among the 32 fish samples, this 1 brown trout, 1 cutthroat trout, both splake, and 3 white sucker samples had selenium concentrations greater than $7.91 \mu \mathrm{g} / \mathrm{g}$ dry weight. Two rainbow trout samples had selenium concentrations that were slightly less than $7.91 \mu \mathrm{g} / \mathrm{g}$. Two other rainbow trout samples were the only samples with selenium concentrations less than $2.0 \mu \mathrm{g} / \mathrm{g}$ dry weight.

Across the United States, background concentrations of selenium in fish tissue other than liver range from 1 to $4 \mu \mathrm{g} / \mathrm{g}$ dry weight (U.S. Department of the Interior, 1998). Lemly (2002) recommends that a whole-body selenium concentration of $4 \mu \mathrm{g} / \mathrm{g}$ dry weight be used as a toxic-effect threshold for overall health and reproductive vigor of freshwater fish. The threshold is described as the level at which toxic effects begin to occur in sensitive species of fish and wildlife. The threshold range for reproductive impairment in sensitive species such as perch, bluegill, and salmon is estimated to be 4 to $6 \mu \mathrm{g} / \mathrm{g}$ dry weight for whole-body fish (U.S. Department of the Interior, 1998). Mortality of adult fish, even sensitive species, only begins to occur at concentrations much higher than threshold levels. For Wolford Mountain Reservoir, all but two fish samples had selenium concentrations greater than $4 \mu \mathrm{g} / \mathrm{g}$ dry weight. 
Table 2. Concentrations of selenium and total mercury in fish collected at three sites in Wolford Mountain Reservoir, Colorado, June 2005.

[cm, centimeters; g, grams; yr, year; $\mu \mathrm{g} / \mathrm{g}$, micrograms per gram; --, no available data]

\begin{tabular}{|c|c|c|c|c|c|c|c|c|c|c|c|}
\hline \multirow[b]{2}{*}{$\begin{array}{l}\text { Site number } \\
\text { (see figure 1, } \\
\text { table 1) }\end{array}$} & \multirow[b]{2}{*}{$\begin{array}{c}\text { Common } \\
\text { name }\end{array}$} & \multirow[b]{2}{*}{ Species } & \multirow[b]{2}{*}{$\begin{array}{l}\text { Total } \\
\text { length } \\
\text { (cm) }\end{array}$} & \multirow[b]{2}{*}{$\begin{array}{c}\text { Weight } \\
\text { (g) }\end{array}$} & \multirow[b]{2}{*}{$\begin{array}{l}\text { Age } \\
(y r)\end{array}$} & \multicolumn{3}{|c|}{ Whole-body fish } & \multicolumn{3}{|c|}{ Muscle plugs, skin-off } \\
\hline & & & & & & $\begin{array}{c}\text { Selenium, } \\
\text { dry weight } \\
(\mu \mathrm{g} / \mathrm{g})\end{array}$ & $\begin{array}{c}\text { Moisture } \\
\text { percent }\end{array}$ & $\begin{array}{c}\text { Selenium, } \\
\text { wet weight } \\
(\mu \mathrm{g} / \mathrm{g})\end{array}$ & $\begin{array}{c}\text { Mercury, } \\
\text { dry weight } \\
(\mu \mathrm{g} / \mathrm{g})\end{array}$ & $\begin{array}{c}\text { Moisture } \\
\text { percent }\end{array}$ & $\begin{array}{c}\text { Mercury, } \\
\text { wet weight } \\
(\mu \mathrm{g} / \mathrm{g})\end{array}$ \\
\hline $\mathrm{F} 1$ & Rainbow trout & Oncorhynchus mykiss & 37.0 & 736 & 7 & 1.05 & 67.4 & 0.34 & 0.0472 & 74.6 & 0.012 \\
\hline $\mathrm{F} 1$ & Rainbow trout & Oncorhynchus mykiss & 38.0 & 507 & 6 & 6.98 & 81.7 & 1.28 & 0.534 & 81.5 & 0.099 \\
\hline $\mathrm{F} 1$ & Rainbow trout & Oncorhynchus mykiss & 35.0 & 485 & 5 & 1.49 & 72.5 & 0.41 & 0.0682 & 78.2 & 0.015 \\
\hline $\mathrm{F} 1$ & Cutthroat trout & Oncorhynchus clarkii & 40.0 & 587 & 6 & 18.57 & 79.0 & 1.80 & 0.375 & 80.5 & 0.073 \\
\hline $\mathrm{F} 1$ & Cutthroat trout & Oncorhynchus clarkii & 39.5 & 559 & 7 & 6.40 & 79.0 & 1.34 & 0.402 & 80.5 & 0.078 \\
\hline $\mathrm{F} 1$ & White sucker & Catostomus commersonii & 38.5 & 614 & $--^{2}$ & ${ }^{3} 6.29$ & 78.6 & ${ }^{3} 1.35$ & 1.61 & 80.1 & ${ }^{4} \mathbf{0 . 3 2 0}$ \\
\hline $\mathrm{F} 1$ & White sucker & Catostomus commersonii & 38.5 & 574 & $--^{2}$ & ${ }^{3} 5.34$ & 79.7 & ${ }^{3} 1.08$ & 1.03 & 83.8 & 0.167 \\
\hline $\mathrm{F} 1$ & White sucker & Catostomus commersonii & 33.5 & 417 & $--^{2}$ & $1,38.09$ & 77.3 & ${ }^{3} 1.84$ & 0.505 & 82.6 & 0.088 \\
\hline $\mathrm{F} 1$ & White sucker & Catostomus commersonii & 37.0 & 535 & $--^{2}$ & ${ }^{3} 6.53$ & 75.4 & ${ }^{3} 1.61$ & 0.579 & 81.4 & 0.108 \\
\hline $\mathrm{F} 1$ & White sucker & Catostomus commersonii & 34.0 & 406 & $--^{2}$ & ${ }^{3} 6.75$ & 76.9 & ${ }^{3} 1.56$ & 0.286 & 82.2 & 0.051 \\
\hline $\mathrm{F} 1$ & White sucker & Catostomus commersonii & 34.3 & 484 & $--^{2}$ & ${ }^{3} 6.51$ & 77.7 & ${ }^{3} 1.45$ & 0.529 & 81.6 & 0.097 \\
\hline $\mathrm{F} 2$ & White sucker & Catostomus commersonii & 35.0 & 470 & 8 & 5.84 & 74.0 & 1.52 & 0.579 & 80.2 & 0.115 \\
\hline $\mathrm{F} 2$ & White sucker & Catostomus commersonii & 33.4 & 423 & 9 & 5.32 & 71.6 & 1.51 & 0.552 & 81.1 & 0.104 \\
\hline $\mathrm{F} 2$ & White sucker & Catostomus commersonii & 36.7 & 550 & 12 & 4.68 & 73.0 & 1.26 & 0.578 & 80.0 & 0.116 \\
\hline $\mathrm{F} 2$ & White sucker & Catostomus commersonii & 32.5 & 405 & 9 & 19.78 & 76.9 & 2.26 & 0.284 & 81.7 & 0.052 \\
\hline $\mathrm{F} 2$ & White sucker & Catostomus commersonii & 34.5 & 432 & 8 & 5.82 & 75.4 & 1.43 & 0.550 & 81.6 & 0.101 \\
\hline $\mathrm{F} 2$ & White sucker & Catostomus commersonii & 35.0 & 435 & 9 & 6.53 & 79.8 & 1.32 & 0.527 & 83.2 & 0.089 \\
\hline $\mathrm{F} 2$ & Cutthroat trout & Oncorhynchus clarkii & 40.0 & 751 & 4 & 7.39 & 77.1 & 1.69 & 0.280 & 80.3 & 0.055 \\
\hline $\mathrm{F} 2$ & Brown trout & Salmo trutta & 26.5 & 200 & 2 & ${ }^{1} 11.7$ & 76.0 & 2.81 & 0.198 & 77.2 & 0.045 \\
\hline $\mathrm{F} 2$ & Brown trout & Salmo trutta & 27.0 & 193 & $--^{2}$ & ${ }^{3} 6.04$ & 76.0 & ${ }^{3} 1.45$ & 0.116 & 76.6 & 0.027 \\
\hline $\mathrm{F} 3$ & Splake & $\begin{array}{l}\text { Salvelinus fontinalis } x \\
\quad \text { Salvelinus namaycush }\end{array}$ & 47.8 & 972 & ${ }^{5} 14$ & 19.38 & 72.5 & 2.58 & 0.264 & 76.6 & 0.062 \\
\hline $\mathrm{F} 3$ & Splake & $\begin{array}{l}\text { Salvelinus fontinalis } x \\
\quad \text { Salvelinus namaycush }\end{array}$ & 44.3 & 728 & ${ }^{5} 11$ & ${ }^{1} 8.09$ & 73.5 & 2.14 & 0.294 & 76.5 & 0.069 \\
\hline $\mathrm{F} 3$ & Rainbow trout & Oncorhynchus mykiss & 38.2 & 540 & 7 & 7.89 & 71.1 & 2.28 & 0.0737 & 76.4 & 0.017 \\
\hline F3 & Brown trout & Salmo trutta & 27.5 & 209 & 3 & 6.28 & 74.8 & 1.58 & 0.127 & 81.9 & 0.023 \\
\hline $\mathrm{F} 3$ & Brown trout & Salmo trutta & 23.5 & 140 & 3 & 7.47 & 76.5 & 1.75 & 0.0911 & 83.2 & 0.015 \\
\hline $\mathrm{F} 3$ & Brown trout & Salmo trutta & 26.5 & 186 & 4 & 7.41 & 76.4 & 1.75 & 0.103 & 79.6 & 0.021 \\
\hline F3 & Rainbow trout & Oncorhynchus mykiss & 35.3 & 335 & 6 & 7.88 & 80.8 & 1.51 & 0.287 & 81.2 & 0.054 \\
\hline F3 & White sucker & Catostomus commersonii & 36.5 & 582 & 8 & 6.85 & 76.6 & 1.60 & 1.02 & 81.2 & 0.192 \\
\hline F3 & White sucker & Catostomus commersonii & 33.8 & 432 & 8 & 5.06 & 72.0 & 1.42 & 0.576 & 81.1 & 0.109 \\
\hline F3 & White sucker & Catostomus commersonii & 36.0 & 554 & 8 & 7.04 & 76.3 & 1.67 & 0.913 & 81.1 & 0.173 \\
\hline F3 & White sucker & Catostomus commersonii & 31.0 & 343 & $--^{2}$ & ${ }^{3} 7.19$ & 76.8 & ${ }^{3} 1.67$ & 0.590 & 82.7 & 0.102 \\
\hline $\mathrm{F} 3$ & White sucker & Catostomus commersonii & 33.7 & 437 & $--^{2}$ & $1,38.01$ & 78.5 & ${ }^{3} 1.72$ & 0.609 & 83.0 & 0.104 \\
\hline
\end{tabular}

${ }^{1}$ Concentration is greater than U.S. Environmental Protection Agency 2004 draft freshwater chronic criterion for selenium in whole-body fish tissue of $7.91 \mu \mathrm{g} / \mathrm{g}$ dry weight (U.S. Environmental Protection Agency, 2006).

${ }^{2}$ Laboratory results for otolith analysis were not available at the time of this report.

${ }^{3}$ Whole-body fish, headless.

${ }^{4}$ Concentration is greater than U.S. Environmental Protection Agency water-quality criterion for mercury for protection of human health of 0.3 ug/g wet weight in fillets (U.S. Environmental Protection Agency, 2001).

${ }^{5}$ Fish age for species not found in Muddy Creek before impoundment is greater than age of the reservoir. Fish may have been stocked in the reservoir as an older fish. 
A detailed study of irrigation drainage in the Uncompahgre Project Area and Grand Valley in western Colorado was conducted between 1991 and 1992 and included analysis of white sucker and brown and rainbow trout whole-body samples for selenium and mercury (Butler and others, 1994). Fish were collected from main-stem rivers and tributaries and from one reservoir and one lake. Parts of the Uncompahgre Project Area and Grand Valley are underlain by Mancos Shale, a Cretaceous marine formation containing selenium that is similar to the Pierre Shale that underlies Wolford Mountain Reservoir. The median whole-body dry-weight selenium concentration in white sucker $(7.1 \mu \mathrm{g} / \mathrm{g})$ collected from the Uncompahgre Project Area and Grand Valley was similar to that in white sucker $(6.53 \mu \mathrm{g} / \mathrm{g})$ collected from Wolford Mountain Reservoir. Median selenium concentrations in brown trout $(5.9 \mu \mathrm{g} / \mathrm{g})$ and rainbow trout $(4.1 \mu \mathrm{g} / \mathrm{g})$ in these two areas were lower than those in brown trout $(7.41 \mu \mathrm{g} / \mathrm{g})$ and rainbow trout $(6.98 \mu \mathrm{g} / \mathrm{g})$ collected from Wolford Mountain Reservoir.

Mercury concentrations in skin-off axial muscle-plug (biopsy) samples in fish from Wolford Mountain Reservoir ranged from 0.012 to $0.320 \mu \mathrm{g} / \mathrm{g}$ wet weight (table 2). All concentrations but one were less than $0.200 \mu \mathrm{g} / \mathrm{g}$ wet weight. One white sucker sample from the near Muddy Creek site had a mercury concentration of $0.320 \mu \mathrm{g} / \mathrm{g}$ wet weight and was the only sample with a concentration greater than the USEPA water-quality criterion for the protection of human health of $0.3 \mu \mathrm{g} / \mathrm{g}$ wet weight in fillets (U.S. Environmental Protection Agency, 2001). The value of $0.3 \mu \mathrm{g} / \mathrm{g}$ is the concentration of mercury in fish tissue that should not be exceeded based on a total fish and shellfish consumption-weighted rate of 17.5 gram (g) fish/day (U.S. Environmental Protection Agency, 2001). For the State of Colorado, the policy for fish consumption advisories states that when mercury is detected at a concentration of $0.5 \mu \mathrm{g} / \mathrm{g}$ wet weight or greater in fish tissue, the body of water from which the fish were sampled is listed as impaired, and additional studies are warranted. All fish collected from Wolford Mountain Reservoir had mercury concentrations that were less than $0.5 \mu \mathrm{g} / \mathrm{g}$.

Mercury concentrations in fish are not only a concern for human health but also can affect fish and wildlife. Beckvar and others (2005) determined a threshold effect level of $0.2 \mu \mathrm{g} / \mathrm{g}$ wet-weight mercury concentration in whole-body fish tissue to be protective of growth, reproduction, development, and behavior. Using the model developed by Peterson and others (2005) to convert muscle plug or biopsy mercury concentration to whole-body mercury concentration, the maximum whole-body concentration of mercury in fish collected in Wolford Mountain Reservoir is estimated to be $0.192 \mu \mathrm{g} / \mathrm{g}$ wet weight. The USFWS criterion concentration of $0.1 \mu \mathrm{g} / \mathrm{g}$ wetweight concentration of mercury in whole-body fish tissue for protection of fish-eating birds and wildlife (Eisler, 1987) was exceeded in 12.5 percent ( 4 of 32) samples. In total, most mercury concentrations in fish samples from the reservoir were less than criteria for the protection of human, fish, and wildlife health and a threshold effect level.
Median wet-weight mercury concentrations in brown trout $(0.073 \mu \mathrm{g} / \mathrm{g})$ and rainbow trout $(0.040 \mu \mathrm{g} / \mathrm{g})$ fillet samples collected as part of the detailed study of irrigation drainage in the Uncompahgre Project Area and Grand Valley in western Colorado between 1991 and 1992 (Butler and others, 1994) were two to three times greater than the median concentration in brown trout $(0.023 \mu \mathrm{g} / \mathrm{g})$ and rainbow trout $(0.017 \mu \mathrm{g} / \mathrm{g})$ collected in Wolford Mountain Reservoir. Even though median mercury concentrations were higher in fish in the Uncompahgre Project Area and Grand Valley, all mercury concentrations in brown and rainbow trout from these two areas were less than the USEPA water-quality criterion for the protection of human health of $0.3 \mu \mathrm{g} / \mathrm{g}$ wet weight (U.S. Environmental Protection Agency, 2001). Fillet samples from white suckers were not collected as part of the irrigation drainage study by Butler and others (1994).

Trace-element concentrations are highly variable in fish and other biological organisms. Bioaccumulation of selenium and mercury in fish is complex and depends on many factors, including fish size and age, fish diet and food-web length, selenium speciation, mercury speciation (especially the amount of methylmercury in an ecosystem), and the quality of sediment and water. Numerous studies have reported interactions between selenium and mercury (Cuvin-Aralar and Furness, 1991; Eisler, 2000; Jacobs, 1989; U.S. Department of the Interior, 1998). Selenium has been shown to affect tissue concentrations of mercury and vice versa. In many studies, selenium has protected plant and animal species from the toxic effects of mercury by suppressing mercury methylation and bioaccumulation. For Wolford Mountain Reservoir, the sample size for each fish species was too small to determine any relation between selenium and mercury.

Dissolved selenium and total mercury concentrations in water samples from two tributaries (Muddy Creek and Alkali Slough) to Wolford Mountain Reservoir and in Wolford Mountain Reservoir (fig. 1, table 1) were retrieved from the USGS National Water Information System database for comparison to selenium and mercury concentrations in fish samples. Water-quality data between 1990 and 2005 were available for Muddy Creek; data for Alkali Slough and the reservoir were available between 1995 and 2004 or 2005 (appendix). For the midlake and near dam sites, two water-column samples were collected during each sampling trip, one sample near the water surface and one near the reservoir bottom.

All dissolved selenium concentrations in Muddy Creek were less than the State of Colorado chronic water-quality standard for dissolved selenium for protection of aquatic life of $4.6 \mu \mathrm{g} / \mathrm{L}$ (fig. 2, appendix; Colorado Department of Public Health and Environment, 2006). Most concentrations were less than laboratory detection levels (appendix). In Alkali Slough, most (17 of 19) concentrations of dissolved selenium were greater than the State of Colorado chronic standard of $4.6 \mu \mathrm{g} / \mathrm{L}$ (fig. 2, appendix; Colorado Department of Public Health and Environment, 2006). All but one sample were collected in July or October. For a given year, selenium 


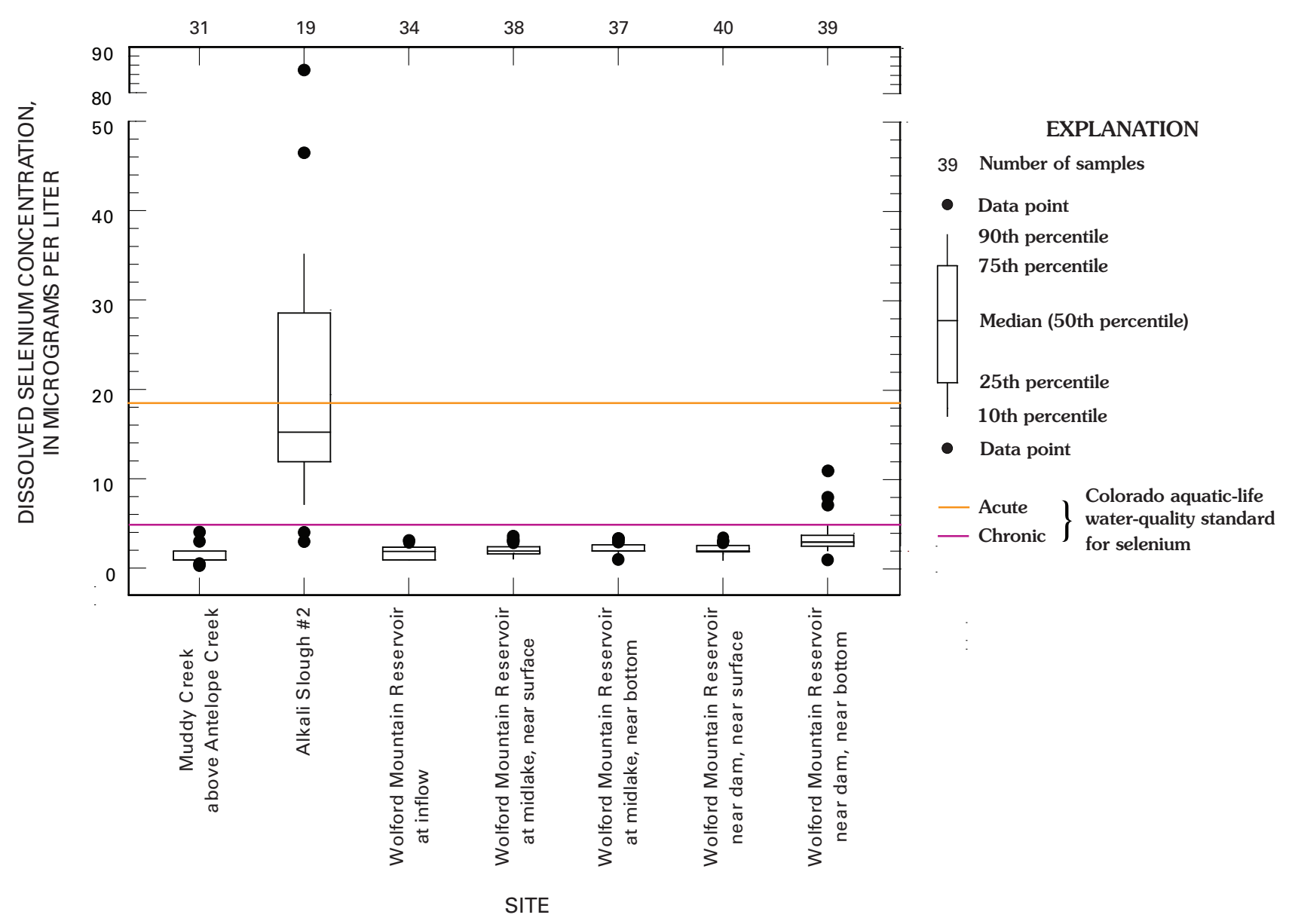

Figure 2. Historic concentrations of dissolved selenium in Muddy Creek, (between 1990 and 2005), Alkali Slough (between 1995 and 2004), and Wolford Mountain Reservoir (between 1995 and 2005), Colorado.

concentrations in Alkali Slough typically were higher for the July sample than the October sample. Instantaneous loads, calculated as the product of streamflow and concentration at the time of sampling, also were higher for July than October. The median instantaneous load for July samples was 354 micrograms per second $(\mu \mathrm{g} / \mathrm{s})$ and for October samples was $106 \mu \mathrm{g} / \mathrm{s}$. Although most concentrations of dissolved selenium in Alkali Slough were elevated, the load of dissolved selenium that flowed into the reservoir was small. Measured discharge was less than or equal to 1 cubic foot per second $\left(\mathrm{ft}^{3} / \mathrm{s}\right)$ for all samples (appendix). Concentrations of total (dissolved and particulate) selenium in Alkali Slough were similar to dissolved concentrations; therefore, loads also would be expected to be similar.

Dissolved selenium concentrations in Wolford Mountain Reservoir primarily were low and less than the State of Colorado chronic water-quality standard for dissolved selenium for protection of aquatic life of $4.6 \mu \mathrm{g} / \mathrm{L}$ (fig. 2, appendix; Colorado Department of Public Health and Environment, 2006). Only six samples, all collected in the reservoir at the near dam site before 1998, had dissolved selenium concentrations greater than $4.6 \mu \mathrm{g} / \mathrm{L}$. Since 1998, all dissolved selenium concentrations in the reservoir have been less than or equal to
$4 \mu \mathrm{g} / \mathrm{L}$ (appendix). Elevated selenium concentrations in fish samples from the reservoir do not reflect the low selenium concentrations in the reservoir water.

Total mercury concentrations in most (224 of 240) water samples from Wolford Mountain Reservoir and the two tributaries were less than laboratory detection levels (appendix). Only six samples had detected total mercury concentrations that were greater than $0.01 \mu \mathrm{g} / \mathrm{L}$ (appendix), the State of Colorado chronic water-quality standard for total mercury for protection of aquatic life (Colorado Department of Public Health and Environment, 2006). Ten samples had detected concentrations that were equal to $0.01 \mu \mathrm{g} / \mathrm{L}$ (appendix). Laboratory detection levels varied from 0.01 to $0.3 \mu \mathrm{g} / \mathrm{L}$ (appendix). Most fish samples also had mercury concentrations that were low and less than the USEPA water-quality criterion for the protection of human health of $0.3 \mu \mathrm{g} / \mathrm{g}$ wet weight in fillets (U.S. Environmental Protection Agency, 2001). Many studies have reported that most selenium and mercury in fish tissue results from selenium and mercury in the diet rather than through gill uptake from water (Lemly, 2002; Luoma and others, 1992; U.S. Department of the Interior, 1998); therefore selenium and mercury in fish in Wolford Mountain Reservoir most likely are not directly related to concentrations in reservoir water. 


\section{Summary and Conclusions}

The U.S. Geological Survey, in cooperation with the Colorado River Water Conservation District, conducted a reconnaissance investigation of selenium and mercury in fish in Wolford Mountain Reservoir, Colorado, in June 2005. Selenium and mercury are trace elements that bioaccumulate in fish and wildlife and can be toxic at high concentrations. In the Western United States, selenium is common in aquatic systems and primarily results from the weathering of marine and continental sedimentary rocks and deposits. The dominant source of mercury to aquatic systems is atmospheric deposition, primarily from coal-powered powerplants. Wolford Mountain Reservoir, in north-central Colorado, is located in an area with seleniferous marine shales and soils. A coal-fired electrical-generating plant is about 65 miles northwest of the reservoir.

A total of 32 game and nongame fish were collected at 3 sites in the reservoir for analysis of selenium and total mercury. Five fish species were collected: white sucker $(n=17)$, brown trout $(n=5)$, rainbow trout $(n=5)$, cutthroat trout $(n=3)$, and splake $(n=2)$. Concentrations of selenium in whole-body fish ranged from 1.05 to 11.7 micrograms per gram $(\mu \mathrm{g} / \mathrm{g})$ dry weight. The U.S. Environmental Protection Agency 2004 draft freshwater chronic criterion for selenium of $7.91 \mu \mathrm{g} / \mathrm{g}$ dry weight concentration in whole-body fish tissue was exceeded in 7 of 32 fish samples. All but two fish samples had selenium concentrations greater than $4 \mu \mathrm{g} / \mathrm{g}$, a toxic effect threshold level for overall health and reproductive vigor in sensitive species of freshwater fish. Concentrations of mercury in skinoff fillet (axial muscle) tissue, determined on tissue biopsy (muscle plug) subsamples, ranged from 0.012 to $0.320 \mu \mathrm{g} / \mathrm{g}$ wet weight. Only one fish sample had a total mercury concentration greater than U.S. Environmental Protection Agency human-health criterion of $0.3 \mu \mathrm{g} / \mathrm{g}$ wet-weight concentration in fillets. All other fish samples had concentrations less than $0.2 \mu \mathrm{g} / \mathrm{g}$. The State of Colorado fish-consumption advisory of $0.5 \mu \mathrm{g} / \mathrm{g}$ wet weight was not exceeded. Converting concentrations of mercury in muscle plug samples to concentrations in whole-body samples, estimated whole body total mercury concentrations for four fish samples (12.5 percent) were greater than $0.1 \mu \mathrm{g} / \mathrm{g}$ wet-weight concentration in whole-body fish tissue, the U.S. Fish and Wildlife Service criterion for protection of fish-eating birds and wildlife.

Historic dissolved selenium and total mercury concentrations in water samples from two tributaries to the reservoir and in the reservoir were compiled and compared. Dissolved selenium concentrations in Muddy Creek were less than the State of Colorado chronic water-quality standard for dissolved selenium for protection of aquatic life of 4.6 micrograms per liter $(\mu \mathrm{g} / \mathrm{L})$. Most concentrations of dissolved selenium in Alkali Slough were greater than $4.6 \mu \mathrm{g} / \mathrm{L}$. Selenium loads flowing into the reservoir from Alkali Slough were small, however, with discharge of 1 cubic foot per second or less. Dissolved selenium concentrations in Wolford Mountain Reservoir primarily were less than $4.6 \mu \mathrm{g} / \mathrm{L}$. Concentrations greater than this level occurred before 1998. All dissolved selenium concentrations in the reservoir since 1998 have been less than or equal to $4 \mu \mathrm{g} / \mathrm{L}$. Total mercury concentrations in most water samples from Muddy Creek, Alkali Slough, and Wolford Mountain Reservoir were less than laboratory detection levels. Only 16 samples had total mercury concentrations that were greater than or equal to $0.01 \mu \mathrm{g} / \mathrm{L}$, the State of Colorado chronic water-quality standard for total mercury for protection of aquatic life. Many studies report that most selenium and mercury in fish tissue results from the presence of selenium and mercury in the diet rather than through gill uptake from water. Selenium and mercury in fish in Wolford Mountain Reservoir most likely are not directly related to selenium and mercury concentrations in reservoir water.

Results of the reconnaissance investigation of selenium and mercury concentrations in fish in Wolford Mountain Reservoir indicate that selenium concentrations were elevated and greater than criterion or threshold effect levels in some or most fish samples, respectively. Most mercury concentrations in fish samples were less than criteria levels.

\section{References Cited}

Baker, R.F., Blanchfield, P.J., Paterson, M.J., Flett, R.J., and Wesson, L., 2004, Evaluation of nonlethal methods for the analysis of mercury in fish tissue: Transactions of the American Fisheries Society, v. 133, p. 568-576.

Beckvar, Nancy, Dillon, T.M., and Read, L.B., 2005, Approaches for linking whole-body fish tissue residues of mercury or DDT to biological effects thresholds: Environmental Toxicology and Chemistry, v. 24, no. 8, p. 2094-2105.

Belzile, Nelson, Chen, Y.-W., Gunn, J.M., Tong, Jian, Alarie, Yves, Delonchamp, Tania, and Lang, C.-Y., 2006, The effect of selenium on mercury assimilation by freshwater organisms: Canadian Journal of Fisheries and Aquatic Sciences, v. 63, p. 1-10.

Bloom, N.S., 1992, On the chemical form of mercury in edible fish and marine invertebrate tissue: Canadian Journal of Fisheries and Aquatic Sciences, v. 49, p. 1010-1017.

Bodaly, R.A., St. Louis, V.L., Paterson, M.J., Fudge, R.J.P., Hall, B.D., Rosenberg, D.M., and Rudd, J.W.M., 1997, Bioaccumulation of mercury in the aquatic food chain in newly flooded areas, in Sigel, A., and Sigel, H., eds., Metal ions in biological systems, v. 34-Mercury and its effects on environment and biology: New York, Marcel Dekker, Inc., p. 259-287.

Butler, D.L., Wright, W.G., Hahn, D.A., Krueger, R.P., and Osmundson, B.C., 1994, Physical, chemical, and biological data for detailed study of irrigation drainage in the Uncompahgre Project Area and in the Grand Valley, west-central Colorado, 1991-92: U.S. Geological Survey Open-File Report 94-110, 146 p. 
Chen, Y.-W., Belzile, Nelson, and Gunn, J.M., 2001, Antagonistic effect of selenium on mercury assimilation by fish populations near Sudbury metal smelters?: Limnology and Oceanography, v. 46, no. 7, p. 1814-1818.

Colorado Department of Public Health and Environment, 2006, Water Quality Control Commission Regulations, No. 33Classifications and numeric standards for Upper Colorado River Basin and North Platte River (planning region 12) and Regulation No. 33, tables: Colorado Department of Public Health and Environment Water Quality Control Commission, variously paginated, accessed October 17, 2006, at http://www.cdphe.state.co.us/regulations/wqccregs/index.html.

Colorado River Water Conservation District, 2006, Wolford Mountain Reservoir: Glenwood Springs, Colo., Colorado River Water Conservation District, accessed April 10, 2006, at http://www.crwcd.org/page_21.

Culvin-Aralar, M.L.A., and Furness, R.W., 1991, Mercury and selenium interaction-A review: Ecotoxicology and Environmental Safety, v. 21, no. 3, p. 348-364.

Eisler, Ronald, 1987, Mercury hazards to fish, wildlife, and invertebrates-A synoptic review: U.S. Fish and Wildlife Service Biological Report 85, v. 1, no. 10, 90 p.

Eisler, Ronald, 2000, Handbook of chemical risk assessmentHealth hazards to humans, plants, and animals: Boca Raton, Fla., Lewis Publishers, p. 1649-1705.

Heinz, G.H., 1996, Selenium in birds, in Beyer, W.N., Heinz, G.H., and Redmon-Norwood, A.W., eds., Environmental contaminants in wildlife-Interpreting tissue concentrations: Boca Raton, Fla., Lewis Publishers, p. $447-458$.

Jacobs, L.W., ed., 1989, Selenium in agriculture and the environment-Proceedings of a symposium sponsored by Divisions A-5, S-4, and S-7 of the American Society of Agronomy and Soil Sciences Society of America, December 2, 1986, New Orleans, La.: Madison, Wisc., American Society of Agronomy, Inc. and Soil Sciences Society of America, Inc., Soil Sciences Society of America Special Publication No. 23, 233 p.

Krabbenhoft, D.P., Wiener, J.G., Brumbaugh, W.G., Olson, M.L., DeWild, J.F., and Sabin, T.J., 1999, A national pilot study of mercury contamination of aquatic ecosystems along multiple gradients in Morganwalp, D.W., and Buxton, H.T., eds., U.S. Geological Survey Toxic Substances Hydrology Program-Proceedings of the technical meeting, Charleston, S.C., March 8-12, 1999: U.S. Geological Survey Water-Resources Investigations Report 99-4018B, 13 p.
Lemly, A.D., 1998, Pathology of selenium poisoning in fish, in Frankenberger, W.T., Jr., and Engberg, R.A., eds., Environmental chemistry of selenium: New York, Marcel Dekker, Inc., p. 281-296.

Lemly, A.D., 2002, Selenium assessment in aquatic ecosystems: New York, Springer-Verlag, Inc., 160 p.

Luoma, S.N., Johns, Carolyn, Fisher, N.S., Steinberg, N.A., Oremland, R.S., and Reinfelder, J.R., 1992, Determination of selenium bioavailability to a benthic bivalve from particulate and solute pathways: Environmental Science and Technology, v. 26, no. 3, p. 485-291.

National Atmospheric Deposition Program, 2005, Total mercury wet deposition 2005: National Atmospheric Deposition Program, accessed October 17, 2005, at http://nadp.sws.uiuc.edu/mdn/maps/.

National Atmospheric Deposition Program and Illinois State Water Survey, 2005, Monitoring mercury deposition [brochure]: National Atmospheric Deposition Program, accessed October 17, 2005, at http://nadp.sws.uiuc.edu/mdn/.

National Research Council, 2000, Toxicology effects of methylmercury: Washington, D.C., National Academy Press, 344 p.

Nielsen, L.A., and Johnson, D.L., 1983, Fisheries techniquesAge determination: Bethesda, Md., The American Fisheries Society, p. 301-324.

Oregon State University, 2000, Average annual precipitation, Colorado [1961-1990]: Oregon State University Spatial Climate Analytical Service, accessed April 11, 2006, at http://www.ocs.orst.edu/pub/maps/Precipitation/Total/ States/CO/co.gif.

Pearson, E., 2000, The analysis of mercury in fish tissue plugs for the purpose of evaluating a potentially non-lethal sampling method: Bismarck, N. Dak., North Dakota Department of Health Report, 9 p.

Peterson, S.A., Van Sickle, J., Hughes, R.M., Schacher, J.A., and Echols, S.F., 2005, A biopsy procedure for determining filet and predicting whole-fish mercury concentration: New York, Springer, Archives of Environmental Contamination and Toxicology, v. 48, p. 99-107.

Raymond, L.J., and Ralston, N.V.C., 2004, Mercury:selenium interactions and health implications: Seychelles Medical and Dental Journal, v. 7, no. 1, p. 72-77.

Ruddy, B.C., 1987, Sediment discharge in Muddy Creek and the effect of sedimentation rate on the proposed Wolford Mountain Reservoir near Kremmling, Colorado: U.S. Geological Survey Water-Resources Investigations Report 87-4011, 22 p. 
St. Louis, V.L., Rudd, J.W.M., Kelly, C.A., Bodaly, R.A., Paterson, M.J., Beaty, K.G., Hesslein, R.H., Heyes, A., and Majewski, A.R., 2004, The rise and fall of mercury methylation in an experimental reservoir: Environmental Science and Technology, v. 38, p. 1348-1358.

Seiler, R.L., Skorupa, J.P., Naftz, D.L., and Nolan, B.T., 2003, Irrigation-induced contamination of water, sediment, and biota in the Western United States-Synthesis of data from the National Irrigation Water Quality Program: U.S. Geological Survey Professional Paper 1655, 123 p.

Stevens, M.R., and Sprague, L.A., 2003, Hydrology and waterquality characteristics of Muddy Creek and Wolford Mountain Reservoir near Kremmling, Colorado, 1990 through 2001: U.S. Geological Survey Water-Resources Investigations Report 03-4073, 82 p., accessed November 29, 2005, at http://pubs.usgs.gov/wri/wri034073/pdf/wrir03-4073.pdf.

Swain, E.B., Engstrom, D.R., Brigham, M.E., Henning, T.A., and Brezonik, P.L., 1992, Increasing rates of atmospheric mercury deposition in midcontinental North America: Science, v. 257, p. 784-787.

Tweto, Ogden, comp., 1979, Geologic map of Colorado, U.S. Geological Survey State Geologic Map, scale 1:500,000.
U.S. Department of the Interior, 1998, Guidelines for the interpretation of the biological effects of selected constituents in biota, water, and sediment-Selenium: U.S. Department of the Interior, National Irrigation Water Quality Program Information Report No. 3, accessed November 29, 2005, at http://www.usbr.gov/niwqp/guidelines/Selenium.pdf.

U.S. Environmental Protection Agency, 2001, Water quality criterion for the protection of human health-Methylmercury: U.S. Environmental Protection Agency EPA-823-R-01-001, accessed April 10, 2006, at http://www.epa.gov/waterscience/ criteria/methymercury/merctitl.pdf.

U.S. Environmental Protection Agency, 2006, Draft selenium aquatic life criterion: U.S. Environmental Protection Agency, accessed April 6, 2006, at http://www.epa.gov/ seleniumcriteria/index.htm.

U.S. Fish and Wildlife Service, 2006, Trace Element Research Laboratory (TERL) analytical methods: U.S. Fish and Wildlife Service Analytical Control Facility, accessed April 10, 2006, at http://www.fws.gov/chemistry/methods_terl_lab.htm.

Wiener, J.G., Krabbenhoft, D.P., Heinz, G.H., and Scheuhammer, A.M., 2002, Ecotoxicology of mercury, Chapter 16, in Hoffman, D.J., Rattner, B.A., Burton, G.A., Jr., and Cairns, John, Jr., eds., Handbook of Ecotoxicology, 2d ed.: Boca Raton, Fla., CRC Press, p. 409-463. 
Appendix. Historic concentrations of dissolved selenium and total mercury in Muddy Creek, Alkali Slough, and Wolford Mountain Reservoir near Kremmling, Colorado.

[ft, feet; $\mathrm{ft}^{3} / \mathrm{s}$, cubic feet per second; $\mu \mathrm{g} / \mathrm{L}$, micrograms per liter --, no data; <, less than; E, estimated. Number in parentheses after site number and name refers to U.S. Geological Survey National Water Information System site identification number. See figure 1 for site locations]

\begin{tabular}{|c|c|c|c|c|c|}
\hline Date & Time & $\begin{array}{c}\text { Sampling } \\
\text { depth } \\
\text { (ft) }\end{array}$ & $\begin{array}{c}\text { Instantaneous } \\
\text { discharge } \\
\left(\mathrm{ft}^{3} / \mathrm{s}\right)\end{array}$ & $\begin{array}{c}\text { Dissolved } \\
\text { selenium } \\
(\mu \mathrm{g} / \mathrm{L})\end{array}$ & $\begin{array}{c}\text { Total } \\
\text { mercury } \\
(\mu \mathrm{g} / \mathrm{L})\end{array}$ \\
\hline \multicolumn{6}{|c|}{ T1: Muddy Creek above Antelope Creek near Kremmling (09041090) } \\
\hline $05 / 10 / 1990$ & $14: 15$ & -- & 152 & $<1$ & 11.2 \\
\hline $09 / 27 / 1990$ & $12: 00$ & -- & 2.6 & $<1$ & $<0.1$ \\
\hline 05/30/1991 & $10: 30$ & -- & 433 & $<1$ & $<0.1$ \\
\hline 09/25/1991 & $12: 30$ & -- & 6.4 & $<1$ & $<0.1$ \\
\hline 05/07/1992 & $12: 00$ & -- & 255 & $<1$ & $<0.1$ \\
\hline 09/03/1992 & $11: 30$ & -- & 8.2 & $<1$ & $<0.1$ \\
\hline 05/17/1993 & $15: 45$ & -- & 585 & $<1$ & $<0.1$ \\
\hline 09/13/1993 & $16: 30$ & -- & 11 & 1 & $<0.1$ \\
\hline 05/04/1994 & $12: 30$ & -- & 146 & $<2$ & $<0.1$ \\
\hline 09/13/1994 & $13: 45$ & -- & 1.9 & $<1$ & $<0.1$ \\
\hline 05/23/1995 & $15: 00$ & -- & 484 & $<1$ & $<0.1$ \\
\hline 09/18/1995 & $14: 40$ & -- & 3.2 & $<1$ & $<0.1$ \\
\hline 05/22/1996 & $12: 00$ & -- & 567 & $<1$ & $<0.1$ \\
\hline 08/28/1996 & $11: 30$ & -- & 5.8 & $<1$ & $<0.1$ \\
\hline 05/14/1997 & $15: 00$ & -- & 742 & $<1$ & $<0.1$ \\
\hline 09/03/1997 & $11: 45$ & -- & 14 & $<1$ & $<0.1$ \\
\hline 07/22/1998 & $12: 45$ & -- & 10 & $<1$ & $<0.1$ \\
\hline 08/11/1998 & $13: 35$ & -- & 16 & $<1$ & $<0.1$ \\
\hline 05/10/1999 & $14: 40$ & -- & 262 & $<1$ & $<0.1$ \\
\hline 08/10/1999 & $14: 00$ & -- & 16 & $<1$ & $<0.1$ \\
\hline $05 / 09 / 2000$ & $14: 25$ & -- & 409 & $<2$ & $<0.3$ \\
\hline $08 / 22 / 2000$ & $14: 00$ & -- & 21 & $<2$ & $<0.3$ \\
\hline 06/06/2001 & $11: 30$ & -- & 67 & $<2$ & -- \\
\hline 08/29/2001 & $9: 15$ & -- & 5.6 & $<2$ & $<0.01$ \\
\hline $06 / 13 / 2002$ & $12: 15$ & -- & 3 & $<4$ & ${ }^{1} \mathrm{E} 0.01$ \\
\hline $07 / 29 / 2002$ & $12: 00$ & -- & 3 & $<2$ & $<0.01$ \\
\hline $05 / 28 / 2003$ & $12: 30$ & -- & 608 & $<3$ & ${ }^{1}$ E 0.02 \\
\hline 08/19/2003 & $11: 30$ & -- & 9.5 & $<3$ & ${ }^{1} \mathrm{E} 0.01$ \\
\hline 05/19/2004 & $12: 30$ & -- & 183 & E 0.3 & ${ }^{1} \mathrm{E} 0.01$ \\
\hline $08 / 11 / 2004$ & $15: 00$ & -- & 2.7 & 0.6 & $<0.02$ \\
\hline $05 / 23 / 2005$ & $12: 20$ & -- & 509 & 0.5 & ${ }^{1} \mathbf{0 . 0 2}$ \\
\hline \multicolumn{6}{|c|}{ T2: Alkali Slough \#2 at Wolford Mountain Reservoir near Kremmling (400812106254800) } \\
\hline $04 / 12 / 1995$ & $15: 30$ & -- & 0.04 & 3 & $<0.2$ \\
\hline 07/16/1996 & $15: 00$ & -- & 1 & ${ }^{2} 28$ & $<0.1$ \\
\hline $10 / 17 / 1996$ & $14: 00$ & -- & 0.3 & ${ }^{2} 12$ & $<0.1$ \\
\hline 07/10/1997 & 9:30 & -- & 1 & ${ }^{2} 30$ & $<0.1$ \\
\hline $10 / 16 / 1997$ & $11: 15$ & -- & 1 & ${ }^{2} 12$ & $<0.1$ \\
\hline 07/21/1998 & $14: 45$ & -- & 0.5 & 225 & $<0.1$ \\
\hline $10 / 14 / 1998$ & $12: 20$ & -- & 0.25 & ${ }^{2} 15$ & $<0.1$ \\
\hline 07/08/1999 & $10: 00$ & -- & 1 & ${ }^{2} 29$ & $<0.2$ \\
\hline $10 / 13 / 1999$ & $13: 00$ & -- & 0.5 & ${ }^{2} 8$ & $<0.3$ \\
\hline $07 / 12 / 2000$ & $10: 45$ & -- & 0.5 & ${ }^{2} 24$ & $<0.3$ \\
\hline $10 / 11 / 2000$ & $15: 20$ & -- & 0.1 & 29 & $<0.1$ \\
\hline 07/03/2001 & $10: 30$ & -- & 0.5 & ${ }^{2} 26$ & $<0.01$ \\
\hline $10 / 04 / 2001$ & 11:00 & -- & E 0.10 & ${ }^{2} 12$ & $<0.01$ \\
\hline $07 / 30 / 2002$ & 8:30 & -- & E 0.10 & ${ }^{2} 14$ & $<0.01$ \\
\hline $10 / 07 / 2002$ & $15: 00$ & -- & 0.1 & 4 & $<0.02$ \\
\hline $07 / 23 / 2003$ & $10: 20$ & -- & 0.1 & ${ }^{2} 33$ & $<0.02$ \\
\hline $10 / 28 / 2003$ & $11: 45$ & -- & 0.1 & ${ }^{2} 46.4$ & $<0.02$ \\
\hline 07/07/2004 & $13: 30$ & -- & 0.06 & ${ }^{2} 84.7$ & $<0.02$ \\
\hline $10 / 19 / 2004$ & $11: 00$ & -- & 0.5 & ${ }^{2} 15.7$ & $<0.01$ \\
\hline
\end{tabular}


Appendix. Historic concentrations of dissolved selenium and total mercury in Muddy Creek, Alkali Slough, and Wolford Mountain Reservoir near Kremmling, Colorado.-Continued

[ft, feet; $\mathrm{ft}^{3} / \mathrm{s}$, cubic feet per second; $\mu \mathrm{g} / \mathrm{L}$, micrograms per liter --, no data; <, less than; E, estimated. Number in parentheses after site number and name refers to U.S. Geological Survey National Water Information System site identification number. See figure 1 for site locations]

\begin{tabular}{|c|c|c|c|c|c|}
\hline Date & Time & $\begin{array}{l}\text { Sampling } \\
\text { depth } \\
\text { (ft) }\end{array}$ & $\begin{array}{c}\text { Instantaneous } \\
\text { discharge } \\
\left(\mathrm{ft}^{3} / \mathrm{s}\right)\end{array}$ & $\begin{array}{c}\text { Dissolved } \\
\text { selenium } \\
(\mu \mathrm{g} / \mathrm{L})\end{array}$ & $\begin{array}{c}\text { Total } \\
\text { mercury } \\
(\mu \mathrm{g} / \mathrm{L})\end{array}$ \\
\hline \multicolumn{6}{|c|}{ W1: Wolford Mountain Reservoir at inflow near Kremmling (401110106244800) } \\
\hline 06/06/1996 & $13: 20$ & 5 & -- & $<1$ & $<0.1$ \\
\hline 07/17/1996 & 13:00 & 5 & -- & 1 & $<0.1$ \\
\hline 08/27/1996 & 14:00 & 5 & -- & 1 & $<0.1$ \\
\hline 10/16/1996 & $11: 40$ & 5 & -- & 2 & $<0.1$ \\
\hline 06/04/1997 & $11: 45$ & 5 & -- & $<1$ & $<0.1$ \\
\hline 07/09/1997 & 12:00 & 5 & -- & 1 & $<0.1$ \\
\hline 09/04/1997 & $12: 00$ & 5 & -- & 2 & $<0.1$ \\
\hline 10/15/1997 & $11: 30$ & 5 & -- & 1 & $<0.1$ \\
\hline 06/10/1998 & 12:00 & 5 & -- & $<1$ & $<0.1$ \\
\hline 07/21/1998 & $11: 20$ & 5 & -- & 1 & $<0.1$ \\
\hline 08/17/1998 & $11: 45$ & 5 & -- & 1 & $<0.1$ \\
\hline 10/05/1998 & $11: 30$ & 10 & -- & 1 & $<0.1$ \\
\hline 06/01/1999 & $11: 20$ & 5 & -- & $<1$ & $<0.1$ \\
\hline 07/22/1999 & $11: 15$ & 10 & -- & 1 & $<0.1$ \\
\hline 08/18/1999 & $11: 35$ & 5 & -- & 2 & $<0.1$ \\
\hline $10 / 22 / 1999$ & $11: 45$ & 7 & -- & 3 & $<0.3$ \\
\hline 06/08/2000 & $11: 15$ & 10 & -- & E 2 & $<0.3$ \\
\hline 07/06/2000 & $11: 40$ & 5 & -- & E 2 & $<0.3$ \\
\hline 08/24/2000 & $11: 30$ & 5 & -- & 1.9 & $<0.3$ \\
\hline $10 / 13 / 2000$ & 11:00 & 5 & -- & 2.6 & $<0.1$ \\
\hline $06 / 21 / 2001$ & $11: 30$ & 7 & -- & 1.5 & ${ }^{1} \mathbf{0 . 0 1}$ \\
\hline 07/10/2001 & $11: 15$ & 5 & -- & 2 & $<0.01$ \\
\hline 08/29/2001 & 12:00 & 3 & -- & -- & $<0.01$ \\
\hline $10 / 11 / 2001$ & $11: 15$ & 3 & -- & 2.2 & $<0.01$ \\
\hline $06 / 14 / 2002$ & $10: 20$ & 5 & -- & 2.8 & ${ }^{1} \mathbf{0 . 0 1}$ \\
\hline $07 / 02 / 2002$ & 11:00 & 5 & -- & 3.1 & $<0.01$ \\
\hline $08 / 22 / 2002$ & $11: 15$ & 5 & -- & 3.1 & $<0.01$ \\
\hline $06 / 26 / 2003$ & $11: 30$ & 5 & -- & 2 & $<0.02$ \\
\hline $07 / 17 / 2003$ & $11: 15$ & 4 & -- & 2.1 & $<0.02$ \\
\hline 08/26/2003 & 12:00 & 5 & -- & 2.2 & $<0.02$ \\
\hline 09/30/2003 & $11: 30$ & 5 & -- & 2.6 & $<0.02$ \\
\hline $10 / 09 / 2003$ & $11: 20$ & 5 & -- & 2.4 & $<0.02$ \\
\hline 06/16/2004 & $11: 45$ & 5 & -- & 1.5 & $<0.02$ \\
\hline $07 / 21 / 2004$ & 12:00 & 5 & -- & 1.7 & $<0.02$ \\
\hline 08/03/2004 & $11: 30$ & 5 & -- & 1.7 & $<0.02$ \\
\hline \multicolumn{6}{|c|}{ W2: Wolford Mountain Reservoir at midlake near Kremmling (400841106240600) } \\
\hline 07/20/1995 & $12: 00$ & 0.1 & -- & 1 & $<0.1$ \\
\hline 07/20/1995 & $12: 15$ & 40 & -- & $<1$ & $<0.1$ \\
\hline 08/31/1995 & $12: 45$ & 0.1 & -- & $<2$ & $<0.1$ \\
\hline 08/31/1995 & 13:00 & 40 & -- & $<1$ & $<0.1$ \\
\hline 10/19/1995 & $10: 15$ & 0.1 & -- & 2 & $<0.1$ \\
\hline 10/19/1995 & $10: 30$ & 35 & -- & 2 & $<0.1$ \\
\hline 06/06/1996 & $9: 45$ & 0.1 & -- & 1 & $<0.1$ \\
\hline 06/06/1996 & 10:00 & 60 & -- & 2 & $<0.1$ \\
\hline 07/17/1996 & 12:00 & 0.1 & -- & 1 & $<0.1$ \\
\hline 07/17/1996 & $12: 15$ & 60 & -- & 3 & $<0.1$ \\
\hline 08/27/1996 & $13: 15$ & 0.1 & -- & 1 & $<0.1$ \\
\hline 08/27/1996 & $13: 30$ & 60 & -- & 2 & $<0.1$ \\
\hline $10 / 16 / 1996$ & $11: 15$ & 0.1 & -- & 2 & $<0.1$ \\
\hline $10 / 16 / 1996$ & $11: 30$ & 50 & -- & 3 & $<0.1$ \\
\hline
\end{tabular}


Appendix. Historic concentrations of dissolved selenium and total mercury in Muddy Creek, Alkali Slough, and Wolford Mountain Reservoir near Kremmling, Colorado.-Continued

[ft, feet; $\mathrm{ft}^{3} / \mathrm{s}$, cubic feet per second; $\mu \mathrm{g} / \mathrm{L}$, micrograms per liter --, no data; <, less than; E, estimated. Number in parentheses after site number and name refers to U.S. Geological Survey National Water Information System site identification number. See figure 1 for site locations]

\begin{tabular}{|c|c|c|c|c|c|}
\hline Date & Time & $\begin{array}{l}\text { Sampling } \\
\text { depth } \\
\text { (ft) }\end{array}$ & $\begin{array}{c}\text { Instantaneous } \\
\text { discharge } \\
\left(\mathrm{ft}^{3} / \mathrm{s}\right)\end{array}$ & $\begin{array}{c}\text { Dissolved } \\
\text { selenium } \\
(\mu \mathrm{g} / \mathrm{L})\end{array}$ & $\begin{array}{c}\text { Total } \\
\text { mercury } \\
(\mu \mathrm{g} / \mathrm{L})\end{array}$ \\
\hline \multicolumn{6}{|c|}{ W2: Wolford Mountain Reservoir at midlake near Kremmling (400841106240600)—Continued } \\
\hline 06/04/1997 & 11:00 & 0.1 & -- & 2 & $<0.1$ \\
\hline 06/04/1997 & $11: 15$ & 60 & -- & 2 & $<0.1$ \\
\hline 07/09/1997 & $11: 15$ & 0.1 & -- & 1 & $<0.1$ \\
\hline 07/09/1997 & $11: 30$ & 60 & -- & 2 & $<0.1$ \\
\hline 09/04/1997 & $11: 30$ & 0.1 & -- & 2 & $<0.1$ \\
\hline 09/04/1997 & $11: 45$ & 60 & -- & 2 & $<0.1$ \\
\hline 10/15/1997 & 11:00 & 0.1 & -- & 2 & $<0.1$ \\
\hline 10/15/1997 & $11: 15$ & 60 & -- & 2 & $<0.1$ \\
\hline 06/10/1998 & 11:00 & 0.1 & -- & 1 & $<0.1$ \\
\hline 06/10/1998 & $11: 15$ & 50 & -- & 2 & $<0.1$ \\
\hline 07/21/1998 & $10: 50$ & 0.1 & -- & 2 & $<0.1$ \\
\hline 07/21/1998 & 11:05 & 65 & -- & 2 & $<0.1$ \\
\hline 08/17/1998 & 11:00 & 0.1 & -- & 2 & $<0.1$ \\
\hline 08/17/1998 & $11: 15$ & 60 & -- & 1 & $<0.1$ \\
\hline $10 / 05 / 1998$ & $10: 45$ & 0.1 & -- & 2 & $<0.1$ \\
\hline 10/05/1998 & 11:00 & 50 & -- & 2 & $<0.1$ \\
\hline 06/01/1999 & $10: 40$ & 0.1 & -- & 2 & $<0.1$ \\
\hline 06/01/1999 & $10: 55$ & 70 & -- & 2 & $<0.1$ \\
\hline $07 / 22 / 1999$ & $10: 30$ & 0.1 & -- & 1 & $<0.1$ \\
\hline 07/22/1999 & $10: 45$ & 60 & -- & 1 & $<0.1$ \\
\hline 08/18/1999 & $10: 55$ & 0.1 & -- & 1 & $<0.1$ \\
\hline 08/18/1999 & 11:00 & 65 & -- & 2 & $<0.1$ \\
\hline $10 / 22 / 1999$ & 11:00 & 0.1 & -- & 3 & $<0.3$ \\
\hline $10 / 22 / 1999$ & $11: 15$ & 55 & -- & E 2 & $<0.3$ \\
\hline 06/08/2000 & $10: 45$ & 0.1 & -- & E 2 & $<0.3$ \\
\hline 06/08/2000 & 11:00 & 67 & -- & 3 & $<0.3$ \\
\hline 07/06/2000 & $10: 30$ & 0.1 & -- & E 2 & $<0.3$ \\
\hline 07/06/2000 & $10: 45$ & 67 & -- & 3 & $<0.3$ \\
\hline 08/24/2000 & $10: 45$ & 0.1 & -- & 2.1 & $<0.3$ \\
\hline 08/24/2000 & 11:00 & 58 & -- & 2 & $<0.3$ \\
\hline $10 / 13 / 2000$ & $10: 30$ & 0.1 & -- & 2.6 & $<0.1$ \\
\hline $10 / 13 / 2000$ & $10: 45$ & 45 & -- & 2.7 & $<0.1$ \\
\hline $06 / 21 / 2001$ & $10: 50$ & -- & -- & 1.9 & $<0.01$ \\
\hline 06/21/2001 & $10: 55$ & -- & -- & 2.7 & ${ }^{1} \mathbf{0 . 0 1}$ \\
\hline 07/10/2001 & $10: 45$ & 0.5 & -- & 1.9 & $<0.01$ \\
\hline 07/10/2001 & 11:00 & 60 & -- & 2 & $<0.01$ \\
\hline 08/29/2001 & $11: 15$ & 0.5 & -- & 2 & $<0.01$ \\
\hline 08/29/2001 & $11: 30$ & 58 & -- & -- & $<0.01$ \\
\hline $10 / 11 / 2001$ & $10: 45$ & 1.0 & -- & 2.2 & $<0.01$ \\
\hline $10 / 11 / 2001$ & $10: 55$ & 50 & -- & 2.1 & $<0.01$ \\
\hline 06/14/2002 & $9: 55$ & 1.0 & -- & 2.9 & ${ }^{1} \mathbf{0 . 0 2}$ \\
\hline $06 / 14 / 2002$ & 10:05 & 45 & -- & 3.3 & ${ }^{1} \mathbf{0 . 0 1}$ \\
\hline 07/02/2002 & $10: 30$ & 1.0 & -- & 3.2 & $<0.01$ \\
\hline 07/02/2002 & $10: 40$ & 45 & -- & 3.4 & $<0.01$ \\
\hline $08 / 22 / 2002$ & $10: 50$ & 1.0 & -- & 3.5 & $<0.01$ \\
\hline $08 / 22 / 2002$ & 11:00 & -- & -- & 2.5 & $<0.01$ \\
\hline 06/26/2003 & 11:00 & 0.1 & -- & 2.4 & $<0.02$ \\
\hline $06 / 26 / 2003$ & $11: 15$ & 45 & -- & 3.1 & $<0.02$ \\
\hline $07 / 17 / 2003$ & $10: 45$ & 0.1 & -- & 2.4 & $<0.02$ \\
\hline $07 / 17 / 2003$ & 11:00 & 45 & -- & 2.6 & $<0.02$ \\
\hline
\end{tabular}


Appendix. Historic concentrations of dissolved selenium and total mercury in Muddy Creek, Alkali Slough, and Wolford Mountain Reservoir near Kremmling, Colorado._-Continued

[ft, feet; $\mathrm{ft}^{3} / \mathrm{s}$, cubic feet per second; $\mu \mathrm{g} / \mathrm{L}$, micrograms per liter --, no data; <, less than; E, estimated. Number in parentheses after site number and name refers to U.S. Geological Survey National Water Information System site identification number. See figure 1 for site locations]

\begin{tabular}{|c|c|c|c|c|c|}
\hline Date & Time & $\begin{array}{c}\text { Sampling } \\
\text { depth } \\
\text { (ft) }\end{array}$ & $\begin{array}{c}\text { Instantaneous } \\
\text { discharge } \\
\left(\mathrm{ft}^{3} / \mathrm{s}\right)\end{array}$ & $\begin{array}{c}\text { Dissolved } \\
\text { selenium } \\
(\mu \mathrm{g} / \mathrm{L})\end{array}$ & $\begin{array}{c}\text { Total } \\
\text { mercury } \\
(\mu \mathrm{g} / \mathrm{L})\end{array}$ \\
\hline \multicolumn{6}{|c|}{ W2: Wolford Mountain Reservoir at midlake near Kremmling (400841106240600)_Continued } \\
\hline $08 / 26 / 2003$ & $11: 30$ & 0.1 & -- & 2.5 & $<0.02$ \\
\hline 08/26/2003 & $11: 45$ & 45 & -- & 2.5 & $<0.02$ \\
\hline 09/30/2003 & 11:00 & 0.1 & -- & 2.2 & $<0.02$ \\
\hline 09/30/2003 & $11: 10$ & 55 & -- & 3 & $<0.02$ \\
\hline $10 / 09 / 2003$ & $10: 50$ & 1.0 & -- & 2.7 & $<0.02$ \\
\hline $10 / 09 / 2003$ & 11:00 & 45 & -- & 2.8 & $<0.02$ \\
\hline 06/16/2004 & 11:10 & 0.5 & -- & 1.8 & $<0.02$ \\
\hline 06/16/2004 & $11: 20$ & 55 & -- & 2.1 & $<0.02$ \\
\hline $07 / 21 / 2004$ & $11: 35$ & 0.5 & -- & 1.8 & $<0.02$ \\
\hline $07 / 21 / 2004$ & $11: 45$ & 55 & -- & 1.9 & $<0.02$ \\
\hline 08/03/2004 & $11: 10$ & 0.5 & -- & 2.1 & $<0.02$ \\
\hline 08/03/2004 & $11: 20$ & 50 & -- & 2.1 & $<0.02$ \\
\hline \multicolumn{6}{|c|}{ W3: Wolford Mountain Reservoir near Kremmling (09041395) } \\
\hline $07 / 20 / 1995$ & 11:00 & 0.1 & -- & 2 & 10.3 \\
\hline 07/20/1995 & $11: 15$ & 80 & -- & -- & $<0.1$ \\
\hline 08/31/1995 & 11:00 & 0.1 & -- & 1 & $<0.1$ \\
\hline 08/31/1995 & $11: 15$ & 70 & -- & 4 & $<0.1$ \\
\hline $10 / 19 / 1995$ & 9:00 & 0.1 & -- & 2 & $<0.1$ \\
\hline $10 / 19 / 1995$ & $9: 15$ & 70 & -- & ${ }^{2} 7$ & $<0.1$ \\
\hline 06/06/1996 & $11: 45$ & 0.1 & -- & 1 & $<0.1$ \\
\hline 06/06/1996 & $12: 00$ & 90 & -- & 3 & $<0.1$ \\
\hline 07/17/1996 & 11:00 & 0.1 & -- & 1 & $<0.1$ \\
\hline 07/17/1996 & $11: 15$ & 90 & -- & ${ }^{2} 5$ & $<0.1$ \\
\hline 08/27/1996 & $11: 15$ & 0.1 & -- & 1 & $<0.1$ \\
\hline 08/27/1996 & $11: 30$ & 100 & -- & 28 & $<0.1$ \\
\hline 10/16/1996 & $10: 15$ & 0.1 & -- & 2 & $<0.1$ \\
\hline 10/16/1996 & $10: 30$ & 90 & -- & ${ }^{2} 11$ & $<0.1$ \\
\hline 06/04/1997 & $10: 00$ & 0.1 & -- & 2 & $<0.1$ \\
\hline 06/04/1997 & $10: 15$ & 110 & -- & 4 & $<0.1$ \\
\hline 07/09/1997 & $10: 25$ & 0.1 & -- & 1 & $<0.1$ \\
\hline 07/09/1997 & $10: 40$ & 100 & -- & 4 & $<0.1$ \\
\hline 09/04/1997 & $10: 30$ & 0.1 & -- & 2 & $<0.1$ \\
\hline 09/04/1997 & $10: 45$ & 100 & -- & ${ }^{25}$ & $<0.1$ \\
\hline 10/15/1997 & 10:00 & 0.1 & -- & 2 & $<0.1$ \\
\hline 10/15/1997 & $10: 15$ & 90 & -- & ${ }^{2} 5$ & $<0.1$ \\
\hline 06/10/1998 & 10:00 & 0.1 & -- & 1 & $<0.1$ \\
\hline 06/10/1998 & $10: 15$ & 110 & -- & $<1$ & $<0.1$ \\
\hline 07/21/1998 & 10:00 & 0.1 & -- & 2 & $<0.1$ \\
\hline $07 / 21 / 1998$ & $10: 15$ & 100 & -- & 2 & $<0.1$ \\
\hline 08/17/1998 & $9: 50$ & 0.1 & -- & 2 & $<0.1$ \\
\hline 08/17/1998 & 10:05 & 100 & -- & 2 & $<0.1$ \\
\hline $10 / 05 / 1998$ & 10:00 & 0.1 & -- & 2 & $<0.1$ \\
\hline $10 / 05 / 1998$ & $10: 15$ & 90 & -- & 2 & $<0.1$ \\
\hline 06/01/1999 & $9: 50$ & 0.1 & -- & 2 & $<0.1$ \\
\hline 06/01/1999 & 10:05 & 100 & -- & 3 & $<0.1$ \\
\hline $07 / 22 / 1999$ & $9: 50$ & 0.1 & -- & 1 & $<0.1$ \\
\hline 07/22/1999 & $10: 10$ & 110 & -- & 2 & $<0.1$ \\
\hline 08/18/1999 & 10:00 & 0.1 & -- & 2 & $<0.1$ \\
\hline 08/18/1999 & $10: 15$ & 100 & -- & 2 & $<0.1$ \\
\hline $10 / 22 / 1999$ & 10:05 & 0.1 & -- & E 2 & $<0.3$ \\
\hline
\end{tabular}


Appendix. Historic concentrations of dissolved selenium and total mercury in Muddy Creek, Alkali Slough, and Wolford Mountain Reservoir near Kremmling, Colorado.-Continued

[ft, feet; $\mathrm{ft}^{3} / \mathrm{s}$, cubic feet per second; $\mu \mathrm{g} / \mathrm{L}$, micrograms per liter --, no data; <, less than; E, estimated. Number in parentheses after site number and name refers to U.S. Geological Survey National Water Information System site identification number. See figure 1 for site locations]

\begin{tabular}{|c|c|c|c|c|c|}
\hline Date & Time & $\begin{array}{c}\text { Sampling } \\
\text { depth } \\
\text { (ft) }\end{array}$ & $\begin{array}{c}\text { Instantaneous } \\
\text { discharge } \\
\left(\mathrm{ft}^{3} / \mathrm{s}\right)\end{array}$ & $\begin{array}{c}\text { Dissolved } \\
\text { selenium } \\
(\mu \mathrm{g} / \mathrm{L})\end{array}$ & $\begin{array}{c}\text { Total } \\
\text { mercury } \\
(\mu \mathrm{g} / \mathrm{L})\end{array}$ \\
\hline \multicolumn{6}{|c|}{ W3: Wolford Mountain Reservoir near Kremmling (09041395)_Continued } \\
\hline $10 / 22 / 1999$ & $10: 20$ & 90 & -- & 4 & $<0.3$ \\
\hline 06/08/2000 & 10:00 & 0.1 & -- & E 2 & $<0.3$ \\
\hline 06/08/2000 & $10: 15$ & 100 & -- & 3 & $<0.3$ \\
\hline 07/06/2000 & $9: 35$ & 0.1 & -- & E 2 & $<0.3$ \\
\hline $07 / 06 / 2000$ & $9: 50$ & 100 & -- & 3 & $<0.3$ \\
\hline $08 / 24 / 2000$ & 10:00 & 0.1 & -- & 2.2 & $<0.3$ \\
\hline $08 / 24 / 2000$ & $10: 15$ & 88 & -- & 3 & $<0.3$ \\
\hline $10 / 13 / 2000$ & $9: 45$ & 0.1 & -- & 2.7 & $<0.1$ \\
\hline $10 / 13 / 2000$ & $10: 00$ & 90 & -- & 3.2 & $<0.1$ \\
\hline 06/21/2001 & $10: 00$ & -- & -- & 1.7 & ${ }^{1} 0.01$ \\
\hline $06 / 21 / 2001$ & $10: 10$ & -- & -- & 3.3 & ${ }^{1} \mathbf{0 . 0 1}$ \\
\hline 07/10/2001 & $10: 05$ & 0.5 & -- & 1.9 & $<0.01$ \\
\hline 07/10/2001 & $10: 20$ & 100 & -- & 3.2 & $<0.01$ \\
\hline 08/29/2001 & $10: 15$ & 0.5 & -- & 2.6 & $<0.01$ \\
\hline 08/29/2001 & $10: 30$ & 99 & -- & 3.8 & $<0.01$ \\
\hline $10 / 11 / 2001$ & $10: 10$ & 1 & -- & 2.4 & ${ }^{1} \mathbf{0 . 0 1}$ \\
\hline $10 / 11 / 2001$ & $10: 15$ & 85 & -- & 3 & $<0.01$ \\
\hline $06 / 14 / 2002$ & $9: 25$ & 1 & -- & 2.8 & $<0.01$ \\
\hline $06 / 14 / 2002$ & $9: 35$ & 80 & -- & 3.1 & $<0.01$ \\
\hline $07 / 02 / 2002$ & $9: 45$ & -- & -- & 3 & $<0.01$ \\
\hline $07 / 02 / 2002$ & $9: 55$ & 80 & -- & 3.3 & $<0.01$ \\
\hline $08 / 22 / 2002$ & $10: 15$ & 1 & -- & 3.5 & $<0.01$ \\
\hline $08 / 22 / 2002$ & $10: 30$ & -- & -- & 3 & $<0.01$ \\
\hline $06 / 26 / 2003$ & $10: 25$ & 0.1 & -- & 2.3 & $<0.02$ \\
\hline $06 / 26 / 2003$ & $10: 35$ & 85 & -- & 3.4 & $<0.02$ \\
\hline $07 / 17 / 2003$ & $10: 15$ & 0.1 & -- & 2.3 & $<0.02$ \\
\hline $07 / 17 / 2003$ & $10: 30$ & 80 & -- & 3 & $<0.02$ \\
\hline $08 / 26 / 2003$ & $10: 50$ & 0.1 & -- & 2.5 & $<0.02$ \\
\hline 08/26/2003 & 11:00 & 90 & -- & 2.9 & ${ }^{1} \mathbf{0 . 0 5}$ \\
\hline $09 / 30 / 2003$ & $10: 30$ & 0.1 & -- & 3.1 & $<0.02$ \\
\hline 09/30/2003 & $10: 40$ & 88 & -- & 2.8 & $<0.02$ \\
\hline $10 / 09 / 2003$ & $10: 15$ & 1 & -- & 2.7 & $<0.02$ \\
\hline $10 / 09 / 2003$ & $10: 30$ & 75 & -- & 2.9 & $<0.02$ \\
\hline 06/16/2004 & $10: 15$ & 0.5 & -- & 1.9 & $<0.02$ \\
\hline 06/16/2004 & $10: 30$ & 100 & -- & 2.3 & $<0.02$ \\
\hline $07 / 21 / 2004$ & 11:00 & 0.1 & -- & 1.8 & $<0.02$ \\
\hline $07 / 21 / 2004$ & $11: 15$ & 90 & -- & 2.2 & $<0.02$ \\
\hline 08/03/2004 & $10: 40$ & 0.1 & -- & 2 & $<0.02$ \\
\hline 08/03/2004 & $10: 50$ & 90 & -- & 2.4 & $<0.02$ \\
\hline $10 / 13 / 2004$ & $12: 45$ & 1 & -- & 2.5 & $<0.01$ \\
\hline $10 / 13 / 2004$ & $12: 50$ & 61 & -- & 2.5 & $<0.01$ \\
\hline 06/16/2005 & 11:05 & 1 & -- & 2.3 & $<0.01$ \\
\hline $06 / 16 / 2005$ & $11: 15$ & 103 & -- & 2.9 & $<0.01$ \\
\hline
\end{tabular}

${ }^{1}$ Concentration is greater than or equal to the State of Colorado chronic water-quality standard for total mercury for protection of aquatic life of $0.01 \mu \mathrm{g} / \mathrm{L}$ (Colorado Department of Public Health and Environment, 2006).

${ }^{2}$ Concentration is greater than or equal to the State of Colorado chronic water-quality standard for dissolved selenium for protection of aquatic life of $4.6 \mu \mathrm{g} / \mathrm{L}$ (Colorado Department of Public Health and Environment, 2006). 


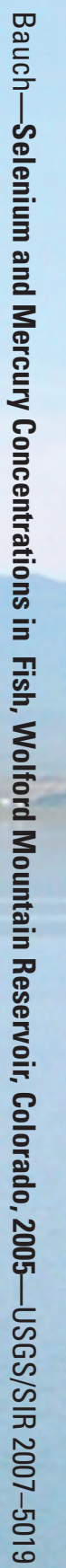

